\title{
TAX COMPLIANCE AND ESTATE PLANNING FOR SAME-SEX COUPLES*
}

\author{
by Samuel H. Grier ${ }^{* *}$ and Tad D. Ransopher ${ }^{* * *}$
}

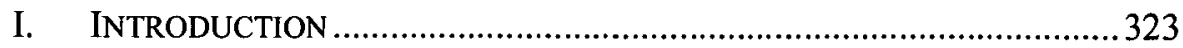

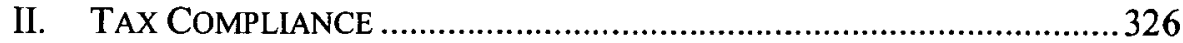

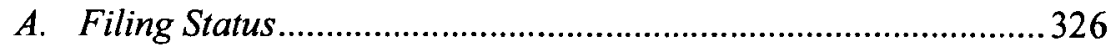

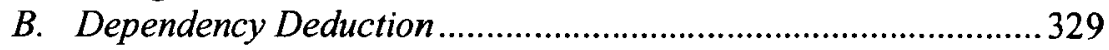

C. Medical Expenses Deduction.......................................................331

D. Employee Health Benefits ..........................................................332

E. Home Mortgage Interest Deduction ................................................

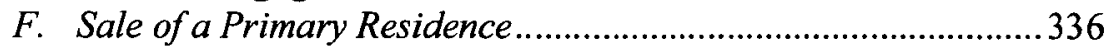

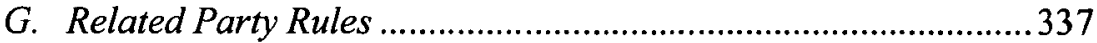

1. Transactions Between Individuals ........................................337

2. Transactions Between Individuals and Business Entities ....340

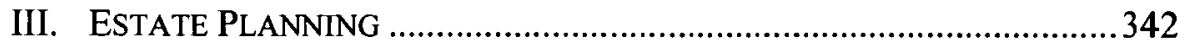

A. The Cohabitation Agreement ......................................................342

B. Non-Probate and Automatic Transfers of Property .....................343

C. Estate and Gift Tax Planning ....................................................347

D. Retirement Savings and Pensions ...............................................348

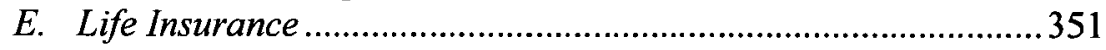

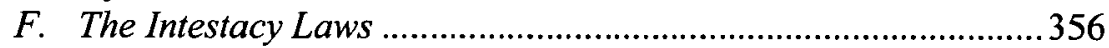

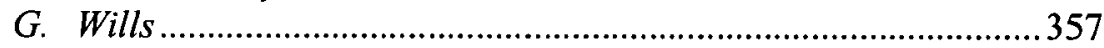

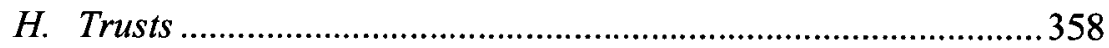

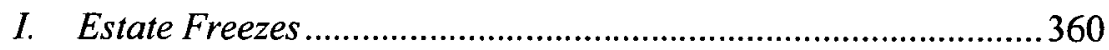

1. Gifts of an Interest in a Business..........................................360

2. Grantor Retained Interest Trusts ........................................361

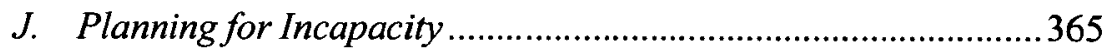

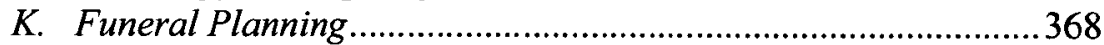

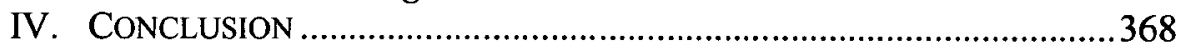

\section{INTRODUCTION}

When the contracting parties have entered into the married state, they have not so much entered into a contract as into a new relation, the rights, duties and obligations of which rest, not upon their agreement, but upon the general law of the State, statutory or common, which defines and

* This article was current as of February 6, 2013.

** Samuel H. Grier is an attorney at King \& Spalding, LLP.

*** Tad D. Ransopher is the Director of the Masters of Taxation Program at Georgia State University. 
prescribes those rights, duties and obligations. ... Their rights under it are determined by the will of the sovereign as evidenced by law. ${ }^{1}$

But for the will of the sovereign, the marriage relationship would be defined by the emotional interaction and the religious significance that the union of two people entails. Governments, however, have provided those who enter into the marriage relationship with certain rights and privileges that were previously unavailable to the parties as individuals. These rights and privileges have come to define the legal relationship of marriage. The legislature and the judiciary not only prescribe the rights and privileges that are gained from entering into marriage, but they control who may enter into this relationship. ${ }^{2}$ Today, changes in social norms and attitudes have given rise to an increase in the number of same-sex couples who openly engage in committed, long-term relationships. For most, the laws of their state do not afford them the right to marry. These couples will approach lawyers and tax professionals seeking to have these relationships legally recognized and have similar rights given to them. The current laws, however, do not afford them the rights and privileges that are given to those who enter into the legally sanctioned marriage relationship.

The marital relationship gives married couples many social and legal privileges that are unavailable to same-sex couples, which affect their taxes, intestate succession, health care, and means of holding property. ${ }^{3}$ The legal relationship of marriage is currently only available to same-sex couples living in Iowa, ${ }^{4}$ Connecticut, ${ }^{5}$ Massachusetts, ${ }^{6}$ Vermont, ${ }^{7}$ New Hampshire, ${ }^{8}$ New York, ${ }^{9}$ and the District of Columbia. ${ }^{10}$ Same-sex marriage has also recently been approved by referendum by voters in Washington, Maryland, and Maine. For same-sex couples not living in these states, the state law advantages afforded to people who marry are unavailable to them. In addition, the legal relationship of marriage - as defined by state lawaffects many federal laws. There are currently about 1,138 provisions in the United States Code in which marriage is a factor in determining rights, privileges, and benefits that are available to the individual. ${ }^{11}$

1. Adams v. Palmer, 51 Me. 480,483 (1863).

2. See 28 U.S.C. $\$ 1738$ (2009) (providing that no state must recognize a same-sex union formed in another state and defining the federal definition of marriage as a legal union between one man and one woman).

3. See Adam Chase, Tax Planning for Same-Sex Couples, 72 DENV. U. L. REV. 359, 360 (1995).

4. See Varnum v. Brien, 763 N.W.2d. 862, 862 (lowa 2009).

5. See 2009 Conn. Acts $1-8$ (Reg. Sess.).

6. See Goodridge v. Dept. of Public Health, 798 N.E.2d. 941, 941 (Mass. 2003).

7. See H. 275, 2007-08 Leg. Sess. (Vt. 2007).

8. See New Hampshire H.B. 73 (2010).

9. See "Marriage Equality Act." A.B. A08354 (2011).

10. See D.C. CODE $\S 46-401$ (2010).

11. See Wendy S. Goffe, Estate Planning for the Unmarried Adult, SR 042 A.L.I.-A.B.A. 567, 571 (2010). 
Tax practitioners must be aware of the provisions in the Internal Revenue Code (I.R.C. or the Code) that will affect same-sex couples who come to them as clients. While the domestic arrangements of these couples may be similar to married couples, they are treated as legal strangers under the Code. ${ }^{12}$ This disadvantages the clients in some situations. There are, however, situations in which the unmarried status of the partners may be advantageous for them. ${ }^{13}$ For example, the numerous anti-abuse rules and related party rules, discussed below, are generally not applicable to samesex couples. ${ }^{14}$ This gives the opportunity for some creative tax planning relating to the partners' business and personal financial affairs. ${ }^{15}$

State laws regarding domestic and inheritance rights, however, generally do not afford any rights to the unmarried same-sex couple's relationship. ${ }^{16}$ As a result, same-sex couples are forced to seek innovative and non-traditional legal relationships to enjoy the rights and privileges denied to them by the current legal system. ${ }^{17}$ Sensitivity to the challenges of creating these legal relationships is important in the area of estate planning law. When creating an estate plan, these devoted same-sex couples have as much of an interest in having their intent carried out as devoted heterosexual couples will. ${ }^{18}$ Achieving that goal, however, may prove to be much more difficult.

It is vitally important that the attorneys helping to create the estate plan are aware of the legal challenges that same-sex couples face. They must work to minimize the risk of the plan being contested and the intent of the partners disregarded. ${ }^{19}$ In addition to minimizing the risk of contest, the attorney and tax practitioners must be aware of the tax implications of setting up an estate plan and employ creative tax strategies to maximize the value of the estate for the benefit of the client and his or her loved one. ${ }^{20}$

Changes in American culture have led to an increased number of people engaging in open same-sex relationships. ${ }^{21}$.This leads to an increase in the number of same-sex couples living as a domestic unit who will be coming to tax practitioners for help with compliance and tax planning. ${ }^{22}$ With the baby-boom generation reaching retirement age, an increase in the number of devoted same-sex couples who seek to create an effective estate

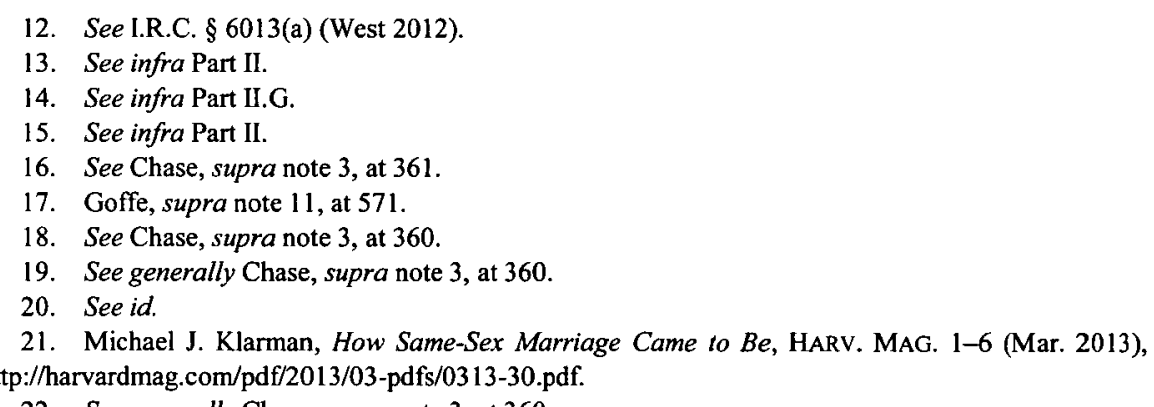

22. See generally Chase, supra note 3 , at 360 . 
plan exists. ${ }^{23}$ Attorneys and tax professionals involved in this process need to be aware of the challenges involved.

This article is organized into two sections and is intended to be a practical discussion that will explore the challenges that same-sex couples will face in these areas. The first section explores the provisions of the I.R.C. that affect same-sex couples as they prepare their tax returns and compute their correct income tax liability each year. ${ }^{24}$ The topics discussed below are also useful in advising couples as to the best way to structure their personal financial affairs and other transactions to take advantage of the tax laws that will affect them. ${ }^{25}$ The second part of this article discusses the many challenges that same-sex couples face in creating an estate plan and discusses the tools that the estate planning attorney can use to effectively facilitate the transfer of property between the same-sex partners after death. ${ }^{26}$ Tax planning, which is essential to any successful estate plan, is also addressed because the unmarried status of most same-sex couples poses unique challenges to the creation of such a plan. ${ }^{27}$ Some of the traditional estate and tax planning methods may still be used to carry out the intent of the partners; some modification, however, may be necessary to give that intent legal effect. ${ }^{28}$

\section{TAX COMPLIANCE}

\section{A. Filing Status}

An individual's marital status determines the filing status that the individual can elect to take when filing a return each year. ${ }^{29}$ Married couples may file separately or jointly, but they may not file as single individuals. $^{30}$ Unmarried persons, however, must file as individuals. ${ }^{31}$ Although a same-sex couple might pool their assets and function as a single economic unit, they must file their annual tax returns as individuals. ${ }^{32}$ The ability to file a return jointly or separately gives the married taxpayer a more favorable tax rate in most cases. ${ }^{33}$

23. See T.P. Gallanis, Aging and the Non-Traditional Family, 32 U. MEM. L. REv. 607, 612 (2002).

24. See infra Part II.

25. See infra Part II.

26. See infra Part III

27. See infra Part III.

28. See infra Part III.

29. See I.R.C. $\$ 6013$ (West 2012).

30. See id.

31. See id.

32. See id. (requiring a joint filing between a husband and wife).

33. See I.R.C. § 1 (West 2012). 
Recent litigation suggests that same-sex couples living in a jurisdiction that recognizes same-sex marriage may soon be eligible to file jointly. ${ }^{34}$ The litigation involves the application of the Federal Defense of Marriage Act (DOMA) to the joint filing provisions of the I.R.C. ${ }^{35}$ DOMA consists of two parts. ${ }^{36}$ The first part suspends the Full Faith and Credit Clause to give states a choice in whether or not to honor same-sex marriages sanctioned by other states. ${ }^{37}$ This section states:

No State, territory, or possession of the United States, or Indian tribe, shall be required to give effect to any public act, record, or judicial proceeding of any other State, territory, possession, or tribe respecting a relationship between persons of the same sex that is treated as a marriage under the laws of such other State, territory, possession, or tribe, or a right or claim arising from such relationship. ${ }^{38}$

The second part of DOMA-codified in volume one, section seven of the United States Code-defines the meaning of the words "marriage" and "spouse" for the purposes of federal law. ${ }^{39}$ This section states:

In determining the meaning of any Act of Congress, or of any ruling, regulation, or interpretation of the various administrative bureaus and agencies of the United States, the word "marriage" means only a legal union between one man and one woman as husband and wife, and the word "spouse" refers only to a person of the opposite sex who is a husband or a wife. ${ }^{40}$

These definitions of spouse and marriage apply to all federal law, including the I.R.C. and subsequent regulations. ${ }^{41}$ Before some states passed legislation allowing for same-sex marriage, same-sex couples were unable to attain the legal relationship of marriage and were thus precluded from filing jointly. ${ }^{42}$

Some states do, however, recognize same-sex marriages, and this has spurred litigation regarding the application of DOMA to these taxpayers who are married under state law. ${ }^{43}$ The United States District Court of the District of Massachusetts has examined the constitutionality of DOMA in

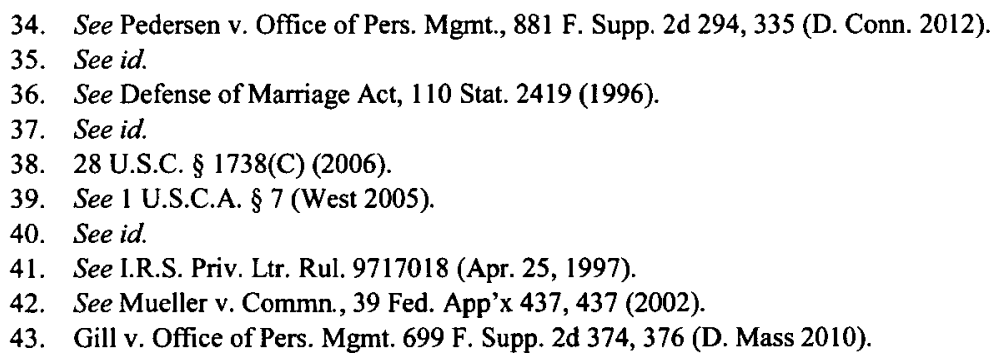

43. Gill v. Office of Pers. Mgmt. 699 F. Supp. 2d 374, 376 (D. Mass 2010). 
the context of filing status and certain survivor benefits. ${ }^{44}$ In Gill v. Office of Personnel Management, seven same-sex couples and three surviving spouses of same-sex marriages challenged the denial of their joint filing status and other marriage-based federal benefits. ${ }^{45}$ All plaintiffs were legally married under the law of Massachusetts, which recognizes same-sex marriage. ${ }^{46}$ The plaintiffs' challenge was based on the argument that the application of section three of DOMA resulted in disparate treatment of similarly situated taxpayers in violation of the Due Process Clause of the Fifth Amendment. ${ }^{47}$

Ruling on cross-motions for summary judgment, the court found the statute unconstitutional as applied to the plaintiffs. ${ }^{48}$ The court noted that eligibility for the benefits denied to the plaintiffs is premised on the marital status of the taxpayers. ${ }^{49}$ Under rational basis review, the court found that the distinction between heterosexual married couples and homosexual married couples, which was required by section three of DOMA, violated the equal protection principles that are embodied in the Fifth Amendment. This ruling was upheld on appeal, and it is unclear whether the Supreme Court will grant certiorari. The court of appeals has stayed enforcement of the ruling until the Supreme Court reviews the appeal or another similar appeal.

Other recent cases have challenged the constitutionality of DOMA. The Second Circuit District Court in New York in Windsor v. United States examined the law in the context of a claim for refund for estate taxes paid. ${ }^{50}$ The court held that DOMA was unconstitutional as applied to the plaintiff and allowed the bequest to the surviving same-sex spouse to qualify for the marital deduction. ${ }^{51}$ This ruling was upheld on appeal. ${ }^{52}$ On December 7 , 2012, the Supreme Court announced that it had granted certiorari for the Windsor case; oral arguments have been scheduled for March 27, 2013. ${ }^{53}$ Two other cases involving married same-sex couples and federal health benefits-Golinski v. Office of Personnel Management ${ }^{54}$ and Pedersen v. Office of Personnel Management ${ }^{55}$-have had similar outcomes in the United States District Court for the Northern District of California and District of Connecticut, respectively, and are awaiting review by the

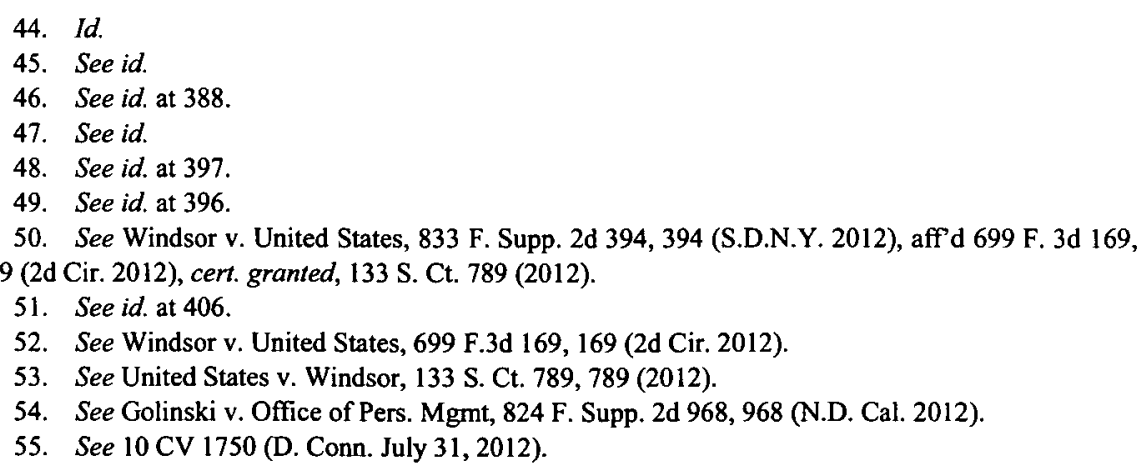


Supreme Court. It appears that this filing status issue should be settled by the end of 2013. ${ }^{56}$ If the Windsor ruling is upheld, it will have the effect of having same-sex marriages recognized as a marriage throughout the I.R.C. and other federal laws.

Note that the above rulings do not apply to civil unions or other such legal relationships recognized by some states. ${ }^{57}$ Absent a state law allowing same-sex marriage, same-sex couples may only file as individuals. ${ }^{58}$ It is possible, however, for a same-sex partner to file under the head of household status if he meets certain requirements. ${ }^{59}$ I.R.C. section 2 defines who may file as head of household. ${ }^{60}$

Pursuant to I.R.C. section 2(b), a taxpayer is entitled to head of household filing status if the taxpayer is not married at the close of the taxable year and has paid more than half the cost of maintaining a home that was the principal home and the principal place of abode for any of the following: (1) a son or daughter, including a legally adopted child, or their descendants or a stepchild of the taxpayer; or (2) any other relative of the taxpayer eligible to be claimed as a dependent under section 152, except those eligible to be claimed under a multiple support agreement. ${ }^{61}$

A further stipulation applies to these tests; the law considers the taxpayer as maintaining a household only if the individual furnishes over half of the cost of maintaining the household during the taxable year. ${ }^{62}$ The next section thoroughly discusses how a person becomes eligible as a dependent of the taxpayer. ${ }^{63}$

\section{B. Dependency Deduction}

A person is considered a dependent of the taxpayer if he or she meets the requirements of section $152\left(\right.$ a) ${ }^{64}$ It is becoming increasingly more common for same-sex partners to have primary custody of children. Usually these same-sex partners have had children in a previous marriage or have adopted children. ${ }^{65}$ It is also possible that another relative is living

56. See generally, Windsor, $133 \mathrm{~S}$. Ct. at 789 (granting certiorari to the Supreme Court).

57. Frank Berall, Tax Consequences of Unmarried Cohabitation, 18 No. 2 PRAC. TAX. LAW 55 (2004).

58. Id.

59. Tara S. Bernard, Tax Tips for Same-Sex Couples, N.Y. Times (Feb. 21, 2013), http://nytimes. com/2010/02/22/tax-tips-for-same-sex-couples-2/.

60. Patricia A. Cain, Taxing Lesbians, 6 S. CAL. Rev. L. \& WOMEN's STUD. 471, 479 (1997).

61. I.R.C. $\S \S 2(b)(1), 152$ (West 2012).

62. $\S 2(b)(1)(B)$.

63. See infra Part II.B.

64. $\S 152(a)$.

65. Same-Sex Parents and Their Children, AM. Assoc. MARRIAGE \& FAMILY THERAPY (Feb. 24, 2013), http://www.aamft.org/imis $15 /$ content/consumer_updates/same-sex-parents-and-their-children. uspx. 
with the couple. ${ }^{66}$ If any of these are the case, it is possible that these people will qualify as dependents of the taxpayer. ${ }^{67}$

I.R.C. section 152(a) defines a dependent as a qualifying child or relative. ${ }^{68}$ To be a qualifying child, the taxpayer must show that: (1) the individual is a child of the taxpayer or a descendent of such child, or the individual is a sibling or step sibling of the taxpayer or a descendant of any such relative; ${ }^{69}(2)$ the taxpayer provided over one-half of the support for the individual for that tax year; ${ }^{70}$ (3) the individual is not yet age nineteen or age twenty-four if he or she is still a student, ${ }^{71}$ and (4) the dependent must not have a gross income in excess of the exemption amount for the year involved. ${ }^{72}$ The test for "qualifying relative" under I.R.C. section 152(d) includes the requirements of support and the gross income limitation shown above. ${ }^{73}$ However, the relationship may be one of: (1) a child or a descendent of a child; (2) a sibling or step sibling; (3) a mother or father or an ancestor of either; (4) a step-mother or step-father; (5) a niece or nephew; (6) an aunt or uncle; (7) or a daughter-in-law, mother or father-inlaw, or a brother or sister-in-law; or (8) an individual other than a spouse who has the same principal place of abode as the taxpayer and is a member of the taxpayer's household. ${ }^{74}$

If anyone in the taxpayer's household meets any of the requirements above, that person may qualify as a dependent of the taxpayer. ${ }^{75}$ The children of the other same-sex partner generally do not meet the requirements of a qualifying relative for the purposes of this section. ${ }^{76}$ Further, the taxpayer partner may be entitled to a child tax credit for each qualifying child who is the taxpayer's dependent. ${ }^{77}$ The child may be a biological child, adopted child, or stepchild but not the child of the other partner. ${ }^{78}$

It is possible for one partner of a same-sex partnership to satisfy the requirements of a qualifying relative under section 152(d) and thus, as a dependent of the other partner. ${ }^{79}$ This is possible if one partner provides

\footnotetext{
66. See id.

67. See $\S 152(\mathrm{c})$.

68. $\$ 152(\mathrm{a})$.

69. $\$ 152(\mathrm{c})(2)$.

70. $\$ 152(\mathrm{c})(1)(\mathrm{D})$.

71. $\$ 152(\mathrm{c})(3)$.

72. $\$ 152(\mathrm{c})$.

73. $\$ 152(a)$.

74. $\$ 152(d)$.

75. Id.
}

76. But see Leonard v. Comm'r., T.C. Summary Opinion 2008-141 (allowing dependency exemption for grandchildren of taxpayer's "friend" with whom taxpayer had been living for 11 years). Because her friend's income was below the threshold for filing, the Tax Court allowed the exemption. Id. This case is non-precedential under Section 7463(b). Id.

77. Cain, supra note 60, at 479.

78. Id. at 480 .

79. $\S 152(d)$. 
more than one-half of the support for the other, the dependent partner is a member of the taxpayer partner's household, and the dependent partner does not have income above a certain limit. ${ }^{80}$ The regulations, however, provide that "[a]n individual is not [a] member of a taxpayer's household if at any time during the taxable year...the relationship between [the taxpayer and the dependent] violat[es] local law.., 81

The question of whether the relationship violates local law will become an issue if a same-sex couple marries in a state that allows samesex marriage and later moves to another state that does not recognize that relationship. ${ }^{82}$ The effect of the holding in Windsor $v$. United States makes this a non-issue because spouses cannot qualify as dependents under the Code. ${ }^{83}$ The problem remains, however, if the couple registers a civil union or a domestic partnership in a state and moves to another state that does not recognize that relationship. ${ }^{84}$ The courts have not addressed this issue, but the ABA suggests that these relationships may violate local law if not recognized in the state and may preclude the dependency status of a partner. $^{85}$

Absent any of the complications created by the legal relationships discussed above, a same-sex partner may qualify as a dependent of the taxpaying partner under section $152 .^{86}$ The IRS has shown that it is willing to accept this position. ${ }^{87}$ In a private letter ruling, the service addressed this issue in the context of an employer providing health benefits to the samesex partner of an employee. ${ }^{88}$ There, the IRS ruled that a same-sex partner might qualify as a dependent of the other partner if the requirements of section $152(\mathrm{~d})$ are met. $^{89}$

\section{Medical Expenses Deduction}

Under section 213 of the I.R.C., a taxpayer may take as an itemized deduction certain medical expenses incurred by the taxpayer or the taxpayer's spouse or dependents. ${ }^{90}$ This is permissible if the total cost of the medical expenses exceeds $7.5 \%$ of the taxpayer's adjusted gross income. ${ }^{91}$ Under this section, deductions of any medical expenses that one

80. Berall, supra note 57, at 58. The exemption amount for 2013 is $\$ 2,000$. I.R.C. $\S 151$ (d) (West 2012)

81. Treas. Reg. $\$ 1.152-1$ (b) (2013) (citation omitted).

82. Berall, supra note 57 , at 55 .

83. See Windsor v. U.S., 833 F. Supp. 2d 394, 405 (S.D.N.Y. 2012).

84. Berall, supra note 57 , at 55 .

85. Goffe, supra note 11 , at 588 .

86. See I.R.C. § 152(d) (West 2012).

87. I.R.S. Priv. Ltr. Rul. 98-50-011 (Sept. 10, 1998).

88. Id.

89. Id.

90. I.R.C. $\S 213$ (West 2012).

91. $\S 213(\mathrm{a})$. 
same-sex partner pays for the benefit of the other will not be deductible unless the other partner qualifies as the dependent or spouse of the taxpayer. 92 In this section, however, the definition of "dependent" relies on the definition in section 152 except that it disregards the limitation on income that the dependent may have, which would ordinarily preclude one from being a qualified relative. ${ }^{93}$ If one partner satisfies the requirements of a qualifying relative, except for the fact that the partner has income over the exemption amount, that partner will qualify as a dependent of the taxpayer under this section. ${ }^{94}$

\section{Employee Health Benefits}

An increasing number of employers are voluntarily offering health benefits to the same-sex partners of their employees. ${ }^{95}$ As of 2012, eighteen states and the District of Columbia offer health benefits to the domestic partners of state employees. ${ }^{96}$ In addition, the majority of major Fortune 500 companies offer these benefits. ${ }^{97}$ While the number of companies that offer these benefits to same-sex domestic partners continues to grow, the tax treatment of these benefits continue to be unfavorable to these employees. $^{98}$

The taxation of employee-provided health benefits is governed by section 106 of the I.R.C. Under section 106, when an employer provides an employee with health insurance benefits, the employee may exclude the value of the benefits from his gross income. ${ }^{99}$ This also applies if the benefits are extended to the spouse or dependents of the employee. ${ }^{100}$ This generally ensures that the employee receives health insurance coverage for the employee, his spouse, and his dependents tax-free. ${ }^{101}$

The added advantage is that the employee can make employee contributions to the health insurance plan by using pre-tax dollars. ${ }^{102}$ Many employers currently require employees to make some contribution to these

92. Id.

93. Id. (cross-referencing section 152 definition, but without regard to section $152(\mathrm{~d})(1)(\mathrm{B})$, which provides that the qualified relative may not have income greater than the exemption amount).

94. See I.R.C. $\S \S 152,213$ (West 2012).

95. Michelle D. Layser, Tax Justice and Same-Sex Domestic Partner Health Benefits: An Analysis of the Tax Equity for Health Plan Beneficiaries Act, 32 U. HAW. L. REV. 73, 76 (2009).

96. Id. (citing States Offering Benefits for Same-Sex Partners of State Employees, NAT'L CONFERENCE STATE LEGISLATURES, http://www.ncsl.org/programs/cyf/stateemployeebenefits.htm (last visited Apr. 21, 2013)).

97. Id.

98. See infra text accompanying note 102.

99. I.R.C. $\$ 106$ (a) (West 2012).

100. Id.; Treas. Reg. $\S 1.106-1$ (1960); Prop. Treas. Reg. $§ 1.106-1,72$ Fed. Reg. 46-421 (Aug. 20, 2007); Notice 2004-79, 2004-49 I.R.B. 898.

101. See $\$ 106(\mathrm{a})$.

102. Treas. Reg. $\S 1.106-1$ (2006). 
health insurance plans. ${ }^{103}$ If the employer requires an employee contribution, the employer will usually allow the employee to take a reduction in salary equal to the amount of the required contribution. ${ }^{104}$ When the employer gives the employee the option to receive health benefits instead of cash, it triggers the application of section 125 .

Section 125 excludes from gross income any benefit received under a written plan between the employer and employee allowing the employee to choose between receiving cash and receiving certain qualified benefits. ${ }^{105}$ A qualified benefit is "any benefit [that] is not includable in the gross income of the employee." discussed in section $106 .^{107}$

Under these rules, if an employer agrees to provide the same-sex partner of an employee with health benefits, the value of the benefits will be included in the income of the employee. ${ }^{108}$ This is the case unless the partner qualifies as a spouse pursuant to the Windsor decision or if a samesex partner qualifies as a dependent of the employee partner. ${ }^{109}$

An employee partner also cannot use pre-tax dollars under a flexible spending account, healthcare spending account, or salary reduction to pay for healthcare for the other partner if the other partner does not qualify as a dependent or a spouse. ${ }^{110}$ Sections 106 and 125 also govern the rules for health flexible spending accounts (FSA). ${ }^{111}$ These accounts are a type of benefit provided by the employer that will reimburse the employee for certain health-related expenses incurred. ${ }^{112}$

Like the contribution requirements discussed above, employees have the option to contribute to an FSA through salary reduction. ${ }^{113}$ This effectively allows a taxpayer to pay for certain medical expenses with pretax dollars. FSAs, however, are subject to the rules contained in section 106 regarding the requirements for exclusion of this benefit from gross income of the employee. ${ }^{114}$ This requires that the employee use the benefit for a spouse or a dependent. ${ }^{115}$ Thus, any portion of the FSA funds used for

103. Layser, supra note 95 , at 87.

104. Id.

105. I.R.C. $\$ 125$ (West 2012).

106. $\S 125(\mathrm{f})$.

107. Id.

108. Layser, supra note 95 , at 84.

109. Goffe, supra note 11 , at 589.

110. Patricia A. Cain, Taxation of Domestic Partner Benefits: The Hidden Costs, 45 U.S.F. L. REV. 481, 483 (2010).

111. See I.R.C. $\$ \S 106,125$ (West 2012).

112. Prop. Treas. Reg. $§ 1.125-5,72$ Fed. Reg. 150, 43938 (Aug. 6, 2007).

113. Layser, supra note 95 , at 84.

114. See $\S 106$.

115. Id. 
medical expenses for the same-sex partner is includable in the gross income of the employee partner. ${ }^{116}$

If one partner is a dependent of the employee partner, then the unfavorable tax treatment of employee benefits may be avoided. As a practical matter, however, it will often be the case that the other partner does not qualify as a dependent under section $152 .{ }^{117}$ As the law stands now, if the beneficiary partner is not a spouse or dependent of the employee spouse, then any employee benefit that goes to the non-employee partner will be included in the employee partner's gross income. ${ }^{118}$

In 2009 , it seemed that this problem was going to be remedied by Congress. ${ }^{119}$ In May of 2009, the House of Representatives introduced the Tax Equity for Health Plan Beneficiaries Act. ${ }^{120}$ Later, the language from this proposed act was incorporated into the Affordable Healthcare for America Act that the House of Representatives passed in November 2009. ${ }^{121}$ The aim of the Tax Equity for Healthcare Beneficiaries Act was to extend the section 106 employer health care benefits exclusion to anyone who is an "eligible beneficiary" of the employee. ${ }^{122}$

The Act would further define an eligible beneficiary as an individual entitled to receive benefits under an accident or health plan. ${ }^{123}$ The effect of this would allow employers to define who is an eligible beneficiary under the terms of their plan. ${ }^{124}$ This language was not included in the final version of the healthcare reform bill that was signed into law. ${ }^{125}$ A new version of this bill, however, was introduced in June of 2011. ${ }^{126}$ The success of this bill would have a substantial effect on taxpayers in same-sex relationships and, like the appeal in the Windsor case, should be monitored by the tax practitioner. The Act is currently under review by the House Subcommittee on Health. ${ }^{127}$

\section{E. Home Mortgage Interest Deduction}

In some instances, there are advantages available to unmarried couples that are unavailable to married couples. One such area is the availability of the home mortgage interest deduction. Section 163 allows a deduction for

116. Id.

117. See Layser, supra note 95 , at 85 .

118. See id.

119. H.R. 2625, 111 th Cong. (2009); S. 1153, 111 th Cong. (2009).

120. H.R. 2625, 111 th Cong. (2009); S. 1153, 111 th Cong. (2009).

121. H.R. 3962, 111 th Cong. $\$ 571$ (2009).

122. See Layser, supra note 95 , at 85 .

123. H.R. 2625, 111 th Cong. \& 2(c)(2) (2009).

124. Layser, supra note 95 , at 108 .

125. H.R. 3962, 111 th Cong.

126. H.R. 2088, 112th Cong.

127. See H.R. 2088, 112 th Cong., LIBRARY CONGRESS, available at http://thomas.loc.gov/cgi-bin/ bdquery/z?d112:HRO2088:@@@\&summ2=m8a (last visited Apr. 21, 2013). 
all interest paid or accrued within the taxable year on indebtedness. ${ }^{128}$ Section 163(h) does not allow any personal interest accrued during the year as a deduction, but it does not include "qualified residence interest" in the definition of personal interest under this section. ${ }^{129}$ Qualified residence interest included acquisition indebtedness with respect to a qualified residence of the taxpayer or home equity indebtedness. ${ }^{130}$ For acquisition indebtedness, the amount that will be classified as such cannot exceed $\$ 1,000,000$ or $\$ 500,000$ if married and filing separately. ${ }^{131}$ For home equity indebtedness, it is limited to $\$ 100,000$, or $\$ 50,000$ if married and filing separately. ${ }^{132}$

Thus, under the statutory scheme discussed above, married couples are limited to mortgage interest deductions for $\$ 1,100,000$ of qualified residence indebtedness. ${ }^{133}$ This figure represents the $\$ 1,000,000$ acquisition indebtedness and $\$ 100,000$ of equity indebtedness that may be shared by married couples. ${ }^{134}$ In the case of same-sex couples and other unmarried couples, each individual will be entitled to the $\$ 1,100,000$ indebtedness discussed above. ${ }^{135}$ There are also a number of residence limitations that work more favorably for unmarried and same-sex couples that disadvantage married couples. ${ }^{136}$

The term "qualified residence" is defined in section $163(\mathrm{~h})(4)(\mathrm{A}) .^{137}$ A qualified residence is the principal residence of the taxpayer as is defined in section 121 and one other residence that is selected by the taxpayer for the purposes of this deduction. ${ }^{138}$ The second residence must be used by the taxpayer as a residence as defined in section $280 \mathrm{~A}(\mathrm{~d})(1) .{ }^{139}$ This section states that a taxpayer uses a dwelling as a residence if he uses the unit for personal purposes for the greater of fourteen days or $10 \%$ of the days for which it is rented out. ${ }^{140}$

Under these limitations, married couples who, for example, own two residences and two vacation homes, may only elect to treat two of the homes as qualified residences for the purposes of the section 163 deduction. ${ }^{141}$ Unmarried couples, however, may claim two residences each

128. I.R.C. $\$ 163$ (a) (West 2000).

129. $\$ 163(\mathrm{~h})(2)(\mathrm{D})$.

130. $\S 163(\mathrm{~h})(3)(\mathrm{A})$.

131. $\$ 163(\mathrm{~h})(3)(\mathrm{B})(\mathrm{ii})$.

132. $\S 163(\mathrm{~h})(3)(\mathrm{C})(\mathrm{ii})$.

133. Patricia A. Cain, Heterosexual Privilege and the Internal Revenue Code, 34 U.S.F. L. REV. 465,490 n. 109 (2000).

134. Id.

135. Id.

136. See infra text accompanying notes $135-40$.

137. $\$ 163(\mathrm{~h})(4)(A)$.

138. Id.

139. I.R.C. $\$ 280 \mathrm{~A}(\mathrm{~d})$ (1) (West 2012).

140. Id.

141. See id. 
and receive deductions for interest accrued on indebtedness for each one, subject to the dollar limitations discussed above. ${ }^{142}$ This may be very beneficial to wealthy same-sex couples who may own more than one home.

\section{F. Sale of a Primary Residence}

When a taxpayer sells a principal place of residence, the taxpayer may exclude the gain from the sale from the taxpayer's gross income. ${ }^{143}$ Section 121 provides that gross income does not include gain from the sale or exchange of property if during the five years preceding the sale the taxpayer used the home as a principal place of residence for a period aggregating two years. ${ }^{144}$ The excluded amount of gain under this section cannot exceed $\$ 250,000$ for someone filing individually or $\$ 500,000$ for a husband and wife who file a joint return. ${ }^{145}$ The exclusion may only apply to one sale every two years. ${ }^{146}$

Ordinarily, a partner in a same-sex couple may only receive an exclusion of $\$ 250,000 .^{147}$ For a same-sex couple to effectively avail themselves to the $\$ 500,000$ limitation that is applicable to married couples for the sale of a single residence, the same-sex couple must own the property jointly. ${ }^{148}$ This allows each partner to be eligible for the $\$ 250,000$ exclusion, effectively giving the couple the equivalent of the $\$ 500,000$ exclusion available to married couples. ${ }^{149}$ In addition to the joint ownership requirement, each partner must fulfill the requirement that both used the property as a primary residence. ${ }^{150}$

It may be that each partner owns property that qualifies for the section 121 exclusion. $^{151}$ If this is the case and they are unmarried, then the partners can sell their homes and both qualify for a $\$ 250,000$ gain exclusion. ${ }^{152}$ Because the partners are not married, the limitation that only one sale every two years qualifies does not apply. ${ }^{153}$

142. See id.

143. I.R.C. $\S 121$ (West 2012).

144. $\S 121(\mathrm{a})$.

145. $\& 121(\mathrm{~b})(1),(2)$.

146. $\S 121(b)(3)$.

147. William P. Kratzke, The Defense of Marriage Act (DOMA) Is Bad Income Tax Policy, $35 \mathrm{U}$. MEM. L. REV. 399, 434 (2005).

148. Id. at 433-34.

149. Id.

150. Id. at 434 .

151. Id.

152. Id. at 435 .

153. Id. 


\section{G. Related Party Rules}

In many sections of the I.R.C., there are measures taken to prevent abuse whenever there is a transfer of property between related individuals. ${ }^{154}$ For unmarried same-sex couples and married same-sex couples, these related party rules are inapplicable if Windsor is overturned on appeal. ${ }^{155}$ The inapplicability of these related party rules gives same-sex partners the opportunity for substantial income tax advantages that are unavailable to married couples. ${ }^{156}$ Tax practitioners are currently using many of the following strategies to successfully reduce the tax liability of their homosexual clients. ${ }^{157}$

\section{Transactions Between Individuals}

One situation in which these related party rules are inapplicable to same-sex partners is with the sale of appreciated property. ${ }^{158}$ Same-sex couples may take advantage of the rules subject to this transaction by structuring the sale as an installment sale. ${ }^{159}$ Section 453 governs the tax treatment of installment sales. ${ }^{160}$ Section 453(e)(1) prevents abuse by related parties where a taxpayer sells property to a related party and the related party subsequently sells to an unrelated third party. ${ }^{161}$ The object of this transaction would be to give the purchasing related party a step-up in basis ${ }^{162}$ while the related seller defers gain until the principal on the note is paid pursuant to the rules in section $453 .{ }^{163}$ The rule in section 453(e)(1), however, states that if the related party purchases the property by way of an installment sale and the purchasing related party then sells the property to an unrelated third party, the gain from the second sale is deemed to be realized by the original seller (i.e., the first related party). ${ }^{164}$

Married spouses are clearly related parties under section 453, which defines "related parties" by reference to the definition found in section 267(b). ${ }^{165}$ Unmarried same-sex partners, however, are not precluded from using this technique to defer gain in the sale of appreciated property. ${ }^{166}$

154. See I.R.C. $\S \S 267(a)(1), 108(e)(4)$ (West 2012).

155. Theodore P. Seto, The Unintended Tax Advantages of Goy Marriage, 65 WASH. \& LEE L. REV. $1529,1548(2008)$.

156. Id. at 1545.

157. Id at 1547-48.

158. Id.

159. Id. at 1548 .

160. I.R.C. $\S 453$ (West 2012).

161. $\S 453(\mathrm{e})(1)$.

162. I.R.C. $\S 1012$ (West 2012).

163. $\S 453$.

164. $\S 453(\mathrm{e})(1)$.

165. I.R.C. $\S 267$ (b) (West 2012).

166. Seto, supra note 155 , at 1549. 
One same-sex partner may sell the other partner the appreciated property via an installment note and the other partner, with a step-up in basis, can then sell the property to a third party and recognize no taxable gain on the sale. ${ }^{167}$ This effectively allows the same-sex couple to lawfully receive the full amount of the proceeds from the sale, while deferring gain for tax purposes. ${ }^{168}$

The related party rules may also be helpful to same-sex couples in avoiding discharge of indebtedness income from being realized. ${ }^{169}$ This will be possible in a situation in which one partner is indebted to a thirdparty creditor and the debt is purchased for less than face value. ${ }^{170}$ Ordinarily the purchase or discharge of the debt for less than the amount owed will result in discharge of indebtedness income for the debtor. ${ }^{171}$ If another party purchases this debt from the creditor, however, the debtor is still obligated to pay the liability and no discharge has occurred that would give rise to income. ${ }^{172}$ When the purchaser of the debt is related to the debtor, the rules in section 108(e)(4) will apply. ${ }^{173}$

The rule in section 108(e)(4) states that if the purchaser of the debt is a related party to the debtor as defined in section 267(b), then the purchase of the debt by that party will be treated as a purchase of the debt by the original debtor. ${ }^{174}$ This will trigger immediate discharge of indebtedness income to the debtor upon the purchase. ${ }^{175}$ If the purchaser is not a related party, then the debtor will not realize that gain upon purchase. ${ }^{176}$

Same-sex partners have used this technique to effectuate what is essentially a discharge of indebtedness without realizing any income for tax purposes. ${ }^{177}$ When the non-debtor partner purchases the debt from the third party creditor, the debtor is still obligated under the note and no discharge has occurred. ${ }^{178}$ Because the couple likely pools its finances, the couple now does not owe any outside debt. ${ }^{179}$ As the debtor makes payments on the note, the payments have the effect of taking money out of one pocket and putting it into another. ${ }^{180}$ This arrangement may also help a same-sex

167. Id.

168. Id. at $\mathbf{1 5 5 0 .}$

169. Id. at $1550-52$.

170. Id. at $\mathbf{1 5 5 0 .}$

171. See generally United States v. Kirby Lumber Co., 284 U.S. 1 (1931); I.R.C. $\S 108$ (West 2012).

172. Seto, supra note 155 , at 1550 .

173. $\S 108(\mathrm{e})(4)$.

174. $\$ 108(\mathrm{e})(4)(\mathrm{A})$.

175. Seto, supra note 155 , at $1550-51$.

176. Id. at 1551 .

177. Id. at 1550 .

178. Id.

179. Id.

180. Id. 
couple avoid gift tax liability from the transfer of money from one partner to the other, as discussed thoroughly below. ${ }^{181}$

Childcare payments may also provide same-sex couples with substantial tax advantages. The rules in section 21 allow a credit against taxable income for expenses associated with dependent care services when childcare is necessary for the taxpayer to work. ${ }^{182}$ This credit is available if expenses are incurred either for the care of a qualifying individual or for household services. ${ }^{183}$ The amount of the credit is $35 \%$ of the expenses incurred, reduced by $1 \%$ for each $\$ 2,000$ by which the taxpayer's gross income exceeds $\$ 15,000 .{ }^{184}$ The percentage cannot be reduced to less than $20 \% .{ }^{185}$

One way same-sex couples may take advantage of this credit is to have the working partner hire the non-working partner to care for the couple's child or children. ${ }^{186}$ If the couple is unmarried, the related party rules contained in section 21 will not preclude this arrangement. ${ }^{187}$ For this section, the credit is not allowable for payments made to the taxpayer's dependent (defined in section 152), spouse, or child who has not reached the age of nineteen. ${ }^{188}$ Thus, payments made to a partner for the care of the couple's children would qualify the taxpayer partner to qualify for credit. ${ }^{189}$

Whether this arrangement benefits same-sex couples depends on the personal and economic aspects of their individual situations. ${ }^{190}$ Payments made to the non-working partner will trigger ordinary income to the partner and may also trigger employment taxes. ${ }^{191}$ However, the result of the employment taxes may result in a contribution toward the partner's eligibility for Social Security benefits. ${ }^{192}$ It may also qualify the nonworking partner for the earned income credit. ${ }^{193}$ All of these factors, including the domestic arrangement of the partners, should be considered in determining whether this arrangement is appropriate.

181. See infra Part III.B.

182. I.R.C. $\$ 21$ (West 2012).

183. $\S 21(\mathrm{~b})(2)$.

184. $\S 21(a)(2)$.

185. Id.

186. See generally Seto, supra note 155 , at 1555 (discussing a hypothetical situation).

187. Id.

188. $\S 21(\mathrm{e})(6)$.

189. Seto, supra note 155 , at 1555 .

190. Id.

191. Id.

192. Id.

193. Id. 


\section{Transactions Between Individuals and Business Entities}

Same-sex partners may also have advantages when running a business through a corporation or other entity. ${ }^{194}$ In response to abusive taxmotivated transactions between family members, Congress enacted several anti-abuse rules intended to prevent such abusive transactions. ${ }^{195}$ Section 267-discussed above-generally prevents the recognition of loss, described as the deduction for interest or expenses with respect to a transaction that occurs between related taxpayers. ${ }^{196}$ The definition of "related taxpayers" in section 267 includes a corporation that is owned or constructively owned by the individual taxpayer engaged in the transaction. ${ }^{197}$ Section 318 provides that stock owned by certain related parties, including spouses, is constructively owned by all of the related parties. ${ }^{198}$

In light of section 267's inapplicability and section 318's constructive ownership rules, unmarried same-sex couples may engage in certain taxmotivated transactions that the Code would otherwise prohibit. ${ }^{199}$ To avoid the application of section 267 , each partner can own no more than $50 \%$ of the company; ${ }^{200}$ for section 318 's constructive ownership rules, however, each partner must own less than $50 \%{ }^{201}$ It is therefore advisable that the couple transfer a small portion of the company to an unrelated party. ${ }^{202}$

If the partners can structure their holdings in a close corporation in the manner discussed above, the couple can prevent the corporation from being treated as "related" for federal income tax purposes. ${ }^{203}$ This introduces many advantageous transactions; for example, a partner and a corporation can engage in some of the transactions discussed above. If either a partner buys property from the corporation in an installment note or the corporation buys from a partner in an installment note, the gain defers until the installment obligation is paid. ${ }^{204}$ The corporation can buy the debt of a partner at a discounted rate without the partner recognizing discharge of indebtedness income. ${ }^{205}$ Other advantages arise if the partners become employees of the corporation, especially if the corporation is an accrual method taxpayer. ${ }^{206}$ If a corporation hires one or both of the partners to

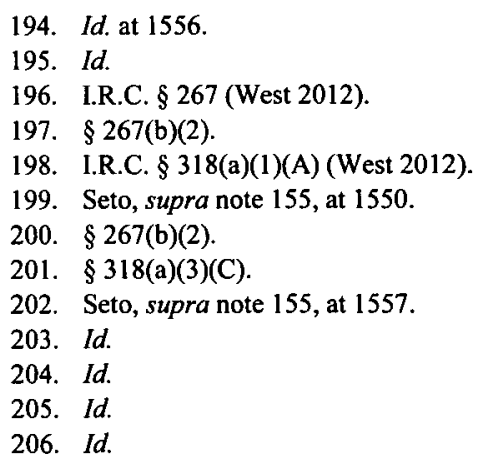


perform services, it may defer the payment of these salaries while incurring an expense that is currently deductible. ${ }^{207}$ This may be used to reduce the corporation's taxable income. ${ }^{208}$ Consequently, as cash method taxpayers, the partners do not pay income taxes on the salary until it is paid. ${ }^{209}$

Same-sex partners may also receive advantageous tax treatment in regards to dividends that are received from the corporation. ${ }^{210}$ Currently, the general rule is that qualified dividends are taxable at the same rate as capital gains. ${ }^{211}$ If a shareholder redeems a portion of his or her stock, the redemption will be treated as a sale or exchange as long as the transaction is not substantially equivalent to a dividend or a disproportionate distribution to the shareholder. ${ }^{212}$ A disproportionate dividend is one that reduces the shareholder's interest in the corporation by more than $20 \% .{ }^{213}$ If a distribution is treated as a sale or exchange, the amount of gain that the shareholder receives will be equal to the amount realized net of the basis in the shares. ${ }^{214}$ If it is treated as a dividend, however, the total amount received will be taxed. ${ }^{215}$

Same-sex couples who own shares in a close corporation have an advantage over married couples in that the constructive ownership rules found in section 318 do not apply. ${ }^{216}$ If a couple is married and one spouse receives a distribution that reduces his interest in the corporation by over $20 \%$, the other spouse's shares will be treated as being owned by the one receiving the distribution. ${ }^{217}$ In most cases, this will preclude the spouse receiving the distribution from having a reduction in his holding of more than $20 \%$. In the case of a same-sex couple who wholly owns a corporation, one partner's shares in the corporation will not be considered owned by the other for the purposes of qualifying for a disproportionate distribution. ${ }^{218}$ Thus, the Code will allow a partner in this situation to redeem more than $20 \%$ of his shares, receive favorable sale or exchange treatment in the transaction, and still allow the couple to retain $100 \%$ control of the corporation. ${ }^{219}$

Similar advantages exist in subchapter $\mathrm{K}$, which can be used if the same-sex couple has formed a partnership or LLC. ${ }^{220}$ For the purposes of

210. See I.R.C. § 1(h)(11) (West 2000).

211. See id.

212. I.R.C. § 302(b)(1), (2) (West 2012).

213. $\S 302(b)(2)(C)$.

214. Seto, supra note 155 , at 1557.

215. Id.

216. Id. at 1558 .

217. Id.

218. Id.

219. Id.

220. See generally I.R.C. $\$ \S 701-09$ (West 2012). 
this paragraph, "partners" shall refer to business partners involved in a partnership governed by subchapter $\mathrm{K}^{221}$ Transactions between partners and the partnership are governed by section $707 .{ }^{222}$ Generally, no loss can be recognized by a partner resulting from a transaction between a partnership and a partner owning more than a 50\% capital interest in the partnership. ${ }^{223}$ For this purpose, section 708 cross-references the related party rules of section 267 for determining whether a partner constructively owns more than $50 \%$ of the capital interests in the partnership. ${ }^{224}$ As the related party transaction principles do not apply, a same-sex couple with each owning $50 \%$ or less of capital interest could structure transactions to generate a capital loss to the partner. ${ }^{225}$

The fact that these transactions are permissible is attributable to the assumption behind the anti-abuse rules-unrelated taxpayers are generally self-interested and will not transfer property to strangers solely for the purpose of avoiding tax. Same-sex couples have fallen through the cracks with regard to these rules. The Windsor decision seems to have cleared up this anomaly with respect to married same-sex couples. ${ }^{226}$ For unmarried same-sex couples who are engaged in trade or business, however, these transactions can be very useful in transferring wealth and minimizing gift and income tax liability for the couple in the aggregate.

\section{ESTATE PlanNING}

\section{A. The Cohabitation Agreement}

The starting point for creating a successful estate plan for a same-sex couple is to draft a cohabitation agreement. For estate planning, the primary purpose of this document is to unequivocally express the intent of the parties and remove any ambiguities that may arise in the future regarding their intent. ${ }^{227}$ As discussed below, evidence of the party's intent going into the relationship will be needed if a legal challenge by a family member or the IRS occurs. ${ }^{228}$

For domestic purposes, same-sex partners may use the cohabitation agreement to define the parameters of their relationship regarding rights and obligations to each other. ${ }^{229}$ Some common areas of the relationship include how income will be shared or separated, how expenses will be

221. See I.R.C. $\$ 761$ (West 2012).

222. See $\S 707$.

223. See id.

224. See $\S 707(b)(3)$.

225. Id.

226. See supra Part II.A.

227. See Berall, supra note 57, at 55.

228. See infra Part III.G.

229. See Goffe, supra note 11 , at 598 . 
handled, how assets will be acquired, and how assets will be split up if they terminate the relationship. ${ }^{230}$ Having these decisions written out in a binding agreement will likely give a degree of certainty to the relationship as the couple moves forward.

For estate planning purposes, the agreement should provide written evidence of the parties' understanding of their relationship and evidence of how they plan to hold assets. Ideally, the cohabitation agreement should begin with a section of recitals. These recitals should describe the circumstances surrounding the relationship, including their intention to create the document. ${ }^{231}$ Other recitals should identify the date that the couple began living together and provide a short history of the parties' relationship with each other. ${ }^{232}$ This section of the document should also state the consideration that is given for the agreement. ${ }^{233}$

The cohabitation agreement should also state how the couple intends to hold property and identify the property that each partner is contributing to the household. ${ }^{234}$ For estate tax purposes, having a record that shows the property that each partner contributes to the household will be beneficial for documenting ownership. ${ }^{235}$ If the couple intends to commingle assets or jointly own assets, the couple should state such intent in the agreement especially for valuable assets, as this will be beneficial in the event of a will contest. $^{236}$

\section{B. Non-Probate and Automatic Transfers of Property}

Because of the nature of domestic relationships, it is very common for a same-sex couple to have joint ownership of assets. ${ }^{237}$ Many same-sex couples jointly own property as a means of facilitating cohabitation and as a way of reflecting how they emotionally view their relationship. ${ }^{238}$ When creating an estate plan, same-sex couples should take advantage of the ability to have jointly owned property with a right of survivorship; at death, this is a very basic way for partners to pass property to the surviving partner. ${ }^{239}$

\section{See id.}

231. See id.

232. Id.

233. Id.

234. See generally Frank S. Berall, The Legal and Tax Status of Persons in Connecticut Civil Unions and Other Unmarried Cohabitants, 78 CONN. B.J. 261 (2004).

235. See infra Part III.C.

236. See infra Part III.G.

237. See Jennifer McGrath, The Ethical Responsibilities of Estate Planning Attorneys in the Representation of Non-Traditional Couples, 27 SEATTLE U. L. REV. 75, 87 (2003).

238. See Chase, supra note 3 , at 360.

239. Id. at 383-84. 
Many devoted same-sex partners will own joint bank accounts. ${ }^{240}$ Joint bank accounts allow the couple to pool their money during their lifetime and as long as the account has a right of survivorship, ownership of the account will automatically pass to the surviving joint owner after the death of the other. ${ }^{241}$ Because of the legal treatment that has traditionally been given to joint ownership interests, there is no requirement that this property be probated. ${ }^{242}$ This legal treatment of joint ownership interests will greatly reduce, if not eliminate, the likelihood of a challenge to the passing of this property. Even if a family member challenges the joint ownership interest in a bank account, most common law jurisdictions hold that a presumption of a gift of funds must be rebutted by clear and convincing evidence of a contrary intent. ${ }^{243}$

There are possible tax consequences to owning a joint bank account that can occur during life, and the couple should be aware of these. ${ }^{244}$ Because the couple is unmarried, any money one partner gives to the other may be viewed as a gift under section 1041 of the Code and may be subject to the gift tax. ${ }^{245}$ This problem may arise in a situation in which one partner contributes all or most of the money into the jointly owned account and the non-contributing partner withdraws more than $\$ 14,000$ during the year. ${ }^{246}$ This will trigger gift tax consequences for the donating partner because the Treasury Regulations make it clear that a gift is made when the amount withdrawn passes from the depositor's control. ${ }^{247}$ If the gift tax is triggered by a withdrawal of funds, the contributing joint owner must file a gift tax return with the IRS. ${ }^{248}$ To avoid this, the couple need only make sure that the non-contributing partner does not personally withdraw more than $\$ 14,000$ during a particular year. ${ }^{249}$

This joint ownership approach can also be used to pass ownership of real estate. ${ }^{250}$ When same-sex partners purchase real property and take title as joint tenants, each partner owns an undivided half interest in the property. ${ }^{251}$ When one joint owner dies, the undivided half interest that the deceased owner had passes to the surviving joint owner automatically and

240. Id. at 383 .

241. See Matthew DuBois, Legal Planning for Gay, Lesbian, and Non-Traditional Elders, 63 ALB. L. REV. 263, 317-18 (1999).

242. See id.

243. See Goffe, supra note 11 , at 607 .

244. See DuBois, supra note 241 , at 318-19.

245. See Chase, supra note 3, at 376.

246. See Anthony C. Infante, The Internal Revenue Code as a Sodomy Statute, 44 SANTA ClARA L. REV. 763, 785 (2004).

247. Treas. Reg. $\$ 25.2511-1(\mathrm{~h})(4)$ (1997).

248. See I.R.C. $\S 2503$ (West 2006); Chase, supra note 3, at 383.

249. See DuBois, supra note 241 , at 318.

250. See Chase, supra note 3, at 383.

251. See id. at $383-84$. 
the surviving owner will have outright ownership of the property. ${ }^{252}$ This transfer, like the transfer of ownership of joint bank accounts, is automatic and occurs without going through probate. ${ }^{253}$

The estate tax consequences of joint ownership in real estate are different from the joint ownership of accounts. ${ }^{254}$ Section 2040 (a) requires that the estate of the first to pass away include the entire value of the jointly owned property. ${ }^{255}$ The executor or trustee can rebut this presumption if they can "demonstrate the extent to which the [surviving joint owner] actually contributed . . . to the purchase or improvement of the property."256 As a practical matter, it is often difficult to show exactly how much the surviving partner contributed to the property; over the years, documents tend to get lost or destroyed. ${ }^{257}$

In addition, "the IRS has never [issued] guidelines for what would be an acceptable [amount] of proof when two [people] have jointly owned property for many years," so it is unclear as to how heavy the burden of proof is for this substantiation. ${ }^{258}$ As a result, the estate of the first partner to die may end up paying estate tax on property that the surviving partner actually owns. ${ }^{259}$ It should be noted that when a heterosexual spouse dies, that spouse's estate includes only one half of the value of the jointly held property with no substantiation required. ${ }^{260}$

The tax court in Estate of Horstmeier $v$. Commissioner addressed the treatment of a home when the deceased same-sex partner owned the home in her name and the surviving partner had no interest in the home. ${ }^{261}$ Here, the decedent's estate included the entire value of the home because the surviving partner had no ownership interest in it, although they resided in the home for many years. ${ }^{262}$ The house, not mentioned in the will, passed into a residuary trust with the surviving partner as beneficiary. ${ }^{263}$ After hearing arguments that the surviving partner received an interest in exchange for household services, the probate court granted the surviving partner a $50 \%$ joint interest in the home, with the trust receiving the other

252. Id.

253. McGrath, supra note 237 , at 88 .

254. Compare I.R.C. $\S 2503$ (West 2006), with I.R.C. $\S 2040$ (a) (West 2006).

255. Anthony C. Infante, Bringing Sexual Orientation and Gender Identity into the Tax Classroom, 59 J. Legal EduC. 3, 24. See also § 2040(a).

256. Infante, supra note 255 , at 24 (discussing Treas. Reg. $\$ 20.2040-1$ (a)(2) (2006)).

257. See id.

258. Patricia A. Cain, Death Taxes: A Critique from the Margin, 48 CLEV. ST. L. REV. 677,694 (2000).

259. See Infante, supra note 255 , at 24.

260. $\$ 2040(\mathrm{~b})$; Infante, supra note 255 , at 24 .

261. Estate of Horstmeier v. Comm'r, 77 T.C.M. 1940, ${ }^{* 1}$ (1999) aff'd sub nom. Scott v. Comm'r, 226 F.3d 871 (7th Cir. 2000).

262. Horstmeier, 77 T.C.M. at *6.

263. Id. 
$50 \%$ interest. ${ }^{264}$ The IRS, however, disregarded this treatment and included the full value in the decedent's estate. ${ }^{265}$

In the tax court, the surviving partner argued that her deceased partner gave her the interest in the house in exchange for performance of household services so it was thus not includable in the estate of the deceased partner. ${ }^{266}$ The court found that, regardless of whether it was a gift or payment for services, the surviving spouse did not contribute to the purchase of the house, and the full amount should therefore be included in the decedent's estate for estate tax purposes. ${ }^{267}$

To prepare for this possible tax liability, same-sex couples need to be sure to keep as many records as possible; records tend to show how much each partner has contributed to the acquisition and maintenance of the property. ${ }^{268}$ The couple should also be aware that if one partner merely gives the other a half interest in the real property as opposed to purchasing and acquiring that interest together, then that transfer may qualify as a taxable gift and be subject to the gift tax. ${ }^{269}$ The transfer of the interest of the property to the other partner could also cause gain to be realized that would trigger income tax if it were a sale of the interest. ${ }^{270}$ There is the possibility of realization of a combination of income and transfer taxes on the transfer if it is a part sale, part gift transfer. ${ }^{271}$ Also, depending on the jurisdiction, the mere transfer of a half interest in real property will not create a joint tenancy; rather, both tenants must acquire the property at the same time to create this legal relationship. ${ }^{272}$ These issues are likely to come up regularly, and the couple should plan for the consequence of transferring an interest in real property. ${ }^{273}$

Another option that may be available to same-sex couples who wish to transfer real property outside of the probate court is the beneficiary deed or the transfer on death deed. ${ }^{274}$ "Currently, ten states have [enacted] legislation that allows for the transfer of real estate outside of probate [court with the] use of a ...transfer on death deed."275 The grantor signs this deed, and it "convey[s] all or a portion of a specific interest [in real property, and] ... expressly stat[es] that th[is] conveyance has no effect

264. Id. at *3-6.

265. Id. at *3.

266. Id. at *4.

267. Id. at *5-6.

268. See id.

269. Infante, supra note 255, at 22.

270. Id. at 23 .

271. Id. at 22 .

272. Id. at $22-24$.

273. See Aimee Bouchard \& Kin Zadworny, Growing Old Together: Estate Planning Concerns for the Aging Same-Sex Couple, 30 W. NEW ENG. L. REV. 713, 735-38 (2008).

274. Id. at 735 .

275. Id. ("Arizona, Arkansas, Colorado, Kansas, Missouri, New Mexico, Nevada, Ohio, Wisconsin, Montana."). 
until [after] the grantor's death."276 At any time during the grantor's life, the grantor may revoke this deed. ${ }^{277}$ Couples who prefer to keep their assets separate may find this method desirable.

\section{Estate and Gift Tax Planning}

As discussed above, certain actions have gift and estate tax consequences but estate planners need to pay special attention to the challenges that same-sex couples face when planning for this tax. ${ }^{278}$ For same-sex couples, planning is a real concern because when the first partner dies, the estate tax becomes an issue. ${ }^{279}$ For married couples, on the other hand, the unlimited marital exemption excludes any property given to the deceased's spouse from the gross estate. ${ }^{280}$ While the unlimited marital gift and estate tax exemption is available to married couples, it is not available to same-sex couples. ${ }^{281}$ Consequently, any improper planning for the mitigation of gift and estate taxes will negatively affect the number of assets available to a surviving partner; therefore, this is something that same-sex couples will certainly want to avoid. ${ }^{282}$

If the partners in a same-sex relationship fail to properly plan their financial dealings with each other, there may be certain gift tax issues that arise when the first partner dies. ${ }^{283}$ On the federal level, same-sex relationships are not recognized as legal relationships so when one partner passes assets to the other partner, the partner who receives the assets is treated as a legal stranger. ${ }^{284}$ One way a same-sex couple can mitigate the possible tax consequences of transferring money to one another is to have a joint checking account. ${ }^{285}$ They can take advantage of the $\$ 14,000$ annual gift limit, which is the amount per person that can be given per year without being subject to the gift tax or reporting requirements. ${ }^{286}$ "Another way same-sex couples may transfer assets is to take advantage of the exclusion from the gift tax paid for medical or educational" expenses of one another. $^{287}$

276. Bouchard \& Zadwomy, supra note 273 , at 735.

277. See id.

278. See discussion supra Part III.A-B.

279. See Goffe, supra note 11, at 571.

280. See I.R.C. $\$ 2056$ (West 2006).

281. See $\$ 2056$.

282. See $\$ 2056$.

283. See Bouchard \& Zadworny, supra note 273, at 731-32.

284. See Anthony C. Infante, Deconstructing the Duty to the Tax System: Unfettering Zealous Advocacy on Behalf of Lesbian and Gay Taxpayers, 61 TAX LAW. 407, 424-25 (2008).

285. See id. at 429.

286. See Bouchard \& Zadworny, supra note 273, at 732. See also I.R.C. $\$ 1$ (West 2006), amended by Pub. L. No. 112-240, 126 Stat. 2313 (2013).

287. Bouchard \& Zadworny, supra note 273, at 732. 
Some same-sex partners have achieved a gift tax-free transfer of assets by setting up an LLC or a partnership. ${ }^{288}$ This can be a very successful tool for same-sex couples to use to minimize gift taxes and share assets, provided that there is a good faith business venture. ${ }^{289}$ After setting up an LLC or partnership, the couple can open up a joint partnership/LLC bank account. ${ }^{290}$ Partnership/LLC agreements allow for great flexibility and, assuming certain conditions are met, the couple can take advantage of the nonrecognition provisions contained in subchapter $\mathrm{K}$, such as the ability to distribute out partnership/LLC assets without the recognition of gain or loss. ${ }^{291}$ In addition, the couple may take advantage of the inapplicability of the related party rules discussed above. ${ }^{292}$ Forming a partnership or LLC not only has gift tax advantages, but it also provides great asset protection. ${ }^{293}$ When one member of the couple dies, there are a number of different planning mechanisms that same-sex partners can use to pass on their interest. ${ }^{294}$ While setting up a partnership or an LLC is one option, this approach may not be appropriate for all same-sex couples because there must be a good faith business venture for this to be effective. ${ }^{295}$ However, it can be very advantageous for couples who can take advantage of this. ${ }^{296}$

\section{Retirement Savings and Pensions}

One important area concerning same-sex couples, especially those nearing retirement, is the federal tax treatment of retirement accounts. If a partner is a participant in an employer-provided defined benefit plan, defined contribution plan, or a qualified individual retirement account (IRA), the Employee Retirement Income Security Act of 1974 will govern the rules regarding the tax treatment of the account. ${ }^{297}$ Congress passed this broad legislation to promote saving for retirement. ${ }^{298}$ To advance this policy, the legislation provides many tax advantages to those who contribute to a qualified plan. ${ }^{299}$ These accounts have substantial income and estate tax consequences that estate planners must consider while creating an estate plan or administering an estate for a same-sex couple. ${ }^{300}$

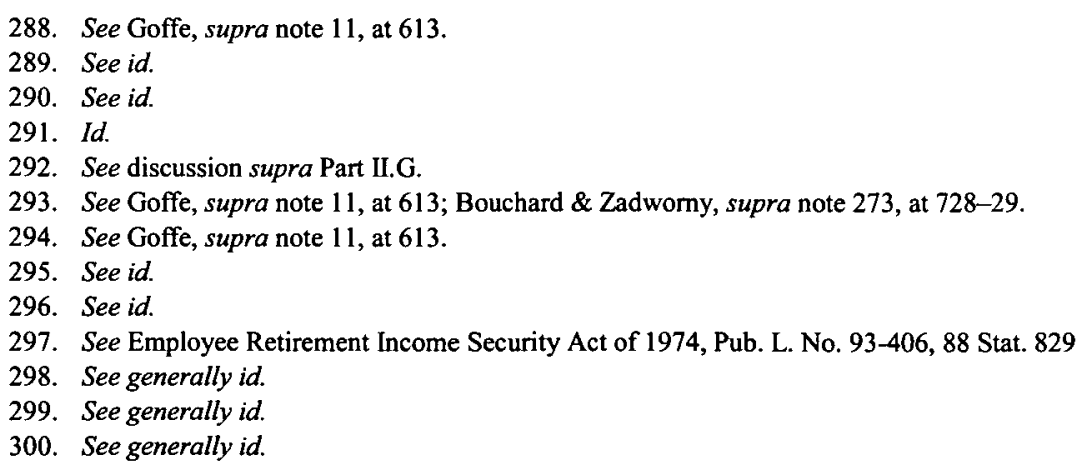


Among the many tax advantages to traditional IRAs is the deduction that section 219 allows for the contribution of cash to a traditional IRA. ${ }^{301}$ Section 219 allows a deduction for the amount an individual contributes; which, for 2013, is up to a limit of $\$ 5,500$. $^{302}$ Under section 219 , spouses are treated separately, meaning that spouses are entitled to deduct the amount they each individually contribute, up to the applicable limit discussed above. ${ }^{303}$ As a result, regardless of whether a same-sex couple is married or unmarried, both partners are entitled to deduct what they contribute to a traditional IRA up to the applicable limit. ${ }^{304}$ While there are, of course, many other rules that are applicable to IRA contributions, such rules are outside of the scope of this article.

Relevant to this discussion, however, are the tax consequences of the transfer of an IRA account after one same-sex partner dies. The estate tax issues involved with qualified plans and IRAs are applicable to all taxpayers. ${ }^{305}$ For the reasons discussed above, however, unmarried samesex couples face an estate tax issue upon the first partner's death because the marital deduction is unavailable to them. ${ }^{306}$

Section 2039 is the primary estate tax provision regarding IRAs and other qualified plans. ${ }^{307}$ It states that:

[The] decedent's gross estate includes the [amount] of any annuity or other payment receivable by a beneficiary by reason of having survived the decedent if ... [ $t$ ]he survivor's annuity arises under a contract (other than insurance policy on the decedent's life). [T] he amount included in the decedent's gross estate is proportionate to the amount of the purchase price contributed by the decedent. ${ }^{308}$

Any contributions made by the decedent's employer to a defined contribution plan will be considered contributions made by the decedent for the purposes of this rule. ${ }^{309}$

Another aspect of the tax treatment of qualified plans is the income tax treatment to the surviving partner. ${ }^{310}$ The partner may name the other partner as the beneficiary of the plan in the event of the employee partner's

301. See I.R.C. $\$ 219$ (West 2006).

302. $8219(\mathrm{~b})(5)$.

303. See News Release, Internal Revenue Service, Announcement of 2013 Pension Plan Limitations (Oct. 18, 2012), available at $\mathrm{http} / / / \mathrm{www}$. irs.gov/uac/2013-Pension-Plan-Limitations.

304. See generally id.

305. See generally Gayle Evans, Estate Planning With Qualified Plans, 17 A.L.I.-A.B.A. EST.

PlAN. COURSE MATERIALS J. 29 (2011), available at SP005 A.L.I.-A.B.A. 317.

306. See I.R.C. § 2056(a) (West 2012).

307. See Evans, supra note 305, at 30 .

308. See id.

309. See id.

310. Harvey B. Wallace, Retirement Benefits Planning Update, 24 PROB. \& PROP. 53 (June 2010). 
death. ${ }^{311}$ Generally, the beneficiary partner may distribute the benefits of the qualified plan to the other partner in the form of a lump-sum payment, an annuity, or may choose for the proceeds to remain in the employer's plan subject to any applicable minimum distribution requirements. ${ }^{312}$ Additionally, the surviving spouse may elect to make a rollover of the deceased partner's qualified plan assets into his or her own traditional IRA on a tax-deferred basis. ${ }^{313}$

A rollover involves a distribution from a qualified plan followed by a contribution of the same property into a qualified IRA within sixty days. ${ }^{314}$ Before 2007, this rollover into the surviving same-sex partner's IRA could not be done on a tax-free basis. ${ }^{315}$ The tax-free treatment was previously only available to a spouse of the deceased. ${ }^{316}$ In 2006, however, Congress passed "the Pension Protection Act of 2006 [which] added I.R.C. section 402(c)(11)(A), effective January 1, 2007, allowing a non-spouse beneficiary to directly rollover qualified retirement benefits via plan-to-plan transfer to an "inherited IRA." 317 In this instance, an inherited IRA is one that is created after the decedent's death, is titled in the name of the deceased for the benefit of the beneficiary, and is payable to the beneficiary. ${ }^{318}$

For the surviving partner to take advantage of this tax-free rollover from an employer's qualified plan to a traditional IRA, certain requirements must be met. ${ }^{319}$ In IRS Notice 2007-7, the IRS gives detailed instructions for how to comply with the requirements of the Pension Protection Act so the rollover to the newly formed inherited IRA will be eligible for tax-free treatment. ${ }^{320}$ The first requirement is that the transfer of funds must be directly from the plan to the new inherited IRA trustee in an electronic transfer. ${ }^{321}$ "A check cannot be issued in the name of the [surviving] beneficiary." 322 If that occurs, the funds will no longer be eligible for inherited IRA treatment. It must be a trustee-to-trustee transfer.

In addition, a new IRA must be created for the purpose of receiving the distribution and will be treated as an inherited IRA. ${ }^{323}$ The funds cannot

311. Id.

312. Id.

313. Id.

314. See I.R.C. $\S 402$ (c)(9) (West 2012).

315. Goffe, supra note 11 , at 591

316. Id.

317. Id.

318. Id.

319. Kathleen R. Sherby, You Made It! Now What? Hot Topics in Planning for the Effective Disposition of Qualified Plans and IRAs, SS039 A.L.I.-A.B.A. 593, 691 (2011).

320. See id. at 692. See also Angelica V. Carrington, Miscellaneous Pension Protections Act Changes, I.R.S. Notice 2007-7.

321. Sherby, supra note 319 , at 691 .

322. Id.

323. Id. 
be transferred into an existing IRA still in the decedent's name. ${ }^{324}$ This newly created inherited IRA must be held for the benefit of the surviving partner. ${ }^{325}$ "The inherited IRA must identify the account as an inherited IRA account, the deceased IRA owner, and [the surviving partner] for whom the account is now held." ${ }^{326}$ The IRS gave examples of acceptable titling, noting that the account can be titled as "Tom Smith as beneficiary of John Smith" and as "John Smith, deceased, IRA for the benefit of Tom Smith." ${ }^{327}$ As a practical matter, "the title should disclose the fact that this is an IRA account, so as not to create future confusion that could result in inadvertent distributions or transfers into non-IRA accounts.",328 Proper planning for the rollover of these kinds of accounts can prevent the surviving partner from incurring substantial income tax liability upon the distribution of the funds from the deceased's qualified plan. ${ }^{329}$

Note that the above rules only apply to the rolling over of assets from a deceased partner's qualified plan into a newly created traditional IRA. ${ }^{330}$ Because of the various other arrangements of deferred compensation and retirement accounts, these rules can cause a lot of confusion. ${ }^{331}$ Before doing any planning in this area, tax professionals should review IRS Notice 2007-7, applicable regulations, and IRS Publication 590 to avoid costly mistakes.

\section{E. Life Insurance}

All couples, whether married or unmarried, should consider getting life insurance as a part of their estate plan. Life insurance can give the surviving partner a source of income and support, and it can also be used to pay the estate taxes of the deceased partner. ${ }^{332}$ If the goal is to provide a source of income to the surviving partner, then a single-life policy on the life of the wage earner, naming the other partner as beneficiary, is often used. $^{333}$ By purchasing life insurance and naming the other partner as beneficiary, a same-sex couple can accomplish a wealth transfer at death that resembles a testamentary disposition, but this type of transfer will not be subject to probate. ${ }^{334}$ Because life insurance policies are not subject to the probate process, they can give the couple privacy that other estate

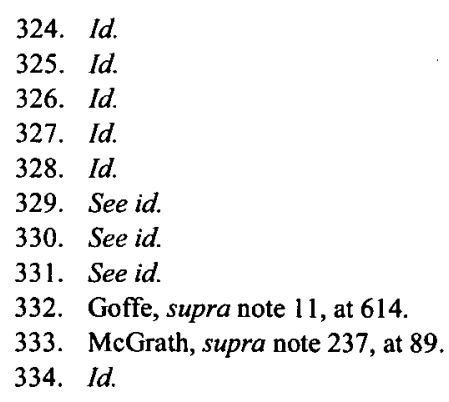


planning tools may not. ${ }^{335}$ Therefore, life insurance policies will likely be desirable to same-sex partners whose relatives are not supportive of their relationship. $^{336}$

When planning for the tax consequences from distribution of life insurance, the insurance contract should qualify as such under the Code; I.R.C. section 7702(a) defines a life insurance contract as a contract that is a life insurance contract under applicable state insurance law. ${ }^{337}$ State insurance laws generally state that a life insurance contract "is not valid unless the policyholder has an 'insurable interest' in the life of the insured." $" 338$ For same-sex relationships in which the beneficiary partner holds the incidents of ownership to the policy, this requirement that the policy holder have an insurable interest in the insured may prove to be an issue if not addressed. ${ }^{339}$ The insurable interest requirement may lead to invalidation of the life insurance contract or possible disputes over the proceeds. ${ }^{340}$

While the exact requirements for a valid insurable interest may vary slightly from state to state, state laws generally require the policyholder to be a family member, to have a reasonable expectation of an advantage of the continued life of the insured, to have a common ownership of property, or to have a business relationship with the insured. ${ }^{341}$ The structure of the life insurance plan between the couple depends on the law of the state where they reside and its requirements for an insurable interest. ${ }^{342}$

Another problem same-sex couples might run into is that insurance companies often require that both the beneficiary and the policyholder have an insurable interest in the insured before issuing the policy; often, a samesex partner will not qualify as having an insurable interest in the other partner. ${ }^{343}$ One way that some same-sex couples have gotten around this problem is to take out the policy and list a beneficiary with an insurable interest then later change the beneficiary to the other partner. ${ }^{344}$ The success of this tactic will depend on the jurisdiction and the insurance company, and it is probably not advisable that the lawyer representing the couple assists in this. ${ }^{345}$ The couple should be advised to talk with a representative of the insurance company before making such a decision. ${ }^{346}$

335. Id.

336. See id.

337. I.R.C. § 7702(a) (West 2012).

338. Goffe, supra note 11 , at 614 .

339. Id.

340. Id.

341. Id.

342. Id.

343. DuBois, supra note 241 , at 326.

344. Peter M. Berkery Jr., Personal financial Planning for Gays and lesbians 335 (1996).

345. See DuBois, supra note 241 , at 326.

346. Id. 
The privacy that life insurance policies offer can be achieved if the beneficiary of the policy holds all of the incidents of ownership to the policy. ${ }^{347}$ As long as the estate of the insured is not subject to the estate tax, the beneficiary does not need to report the receipt of the proceeds. ${ }^{348}$ If the estate of the insured is subject to the estate tax, however, the beneficiary must report the receipt of the proceeds to the IRS. ${ }^{349}$ This is done with a Form 712 that indicates the recipient and the amount of the proceeds. ${ }^{350}$ The proceeds that the beneficiary receives will not generally be subject to the income $\operatorname{tax}^{351}$ under this arrangement, but the beneficiary must nonetheless report receipt of the proceeds. ${ }^{352}$ Note that insurance contracts owned at death will be included in the taxable estate of the insured; the consequences of this will be discussed further below. ${ }^{353}$

The proceeds of life insurance can also be used to pay for the estate taxes of the deceased partner, assuming that the estate is subject to the estate tax. ${ }^{354}$ This type of planning for same-sex couples will differ significantly from planning for traditional heterosexual couples. ${ }^{355}$ Traditional married couples can take advantage of the unified credit and the unlimited marital deduction to postpone the estate tax issue until the surviving spouse dies. ${ }^{356}$ Same-sex couples "cannot take advantage of the unlimited marital deduction," so the estate tax immediately becomes an issue at the death of the first partner regardless of whether the surviving partner receives the majority of the property. ${ }^{357}$ This is when the government may take out a chunk of the estate that the surviving partner may rely on to sustain the partner's established standard of living. ${ }^{358}$

One strategy used to address this problem is to use first-to-die insurance policies. ${ }^{359}$ These policies will cover the couple and will pay out when the first partner dies, giving the surviving partner the extra funds needed to help pay the estate taxes. ${ }^{360}$ This tax planning differs from traditional married couples, who would generally take out a second-to-die policy to address the estate tax issue. ${ }^{361}$ The laws of the jurisdiction and the

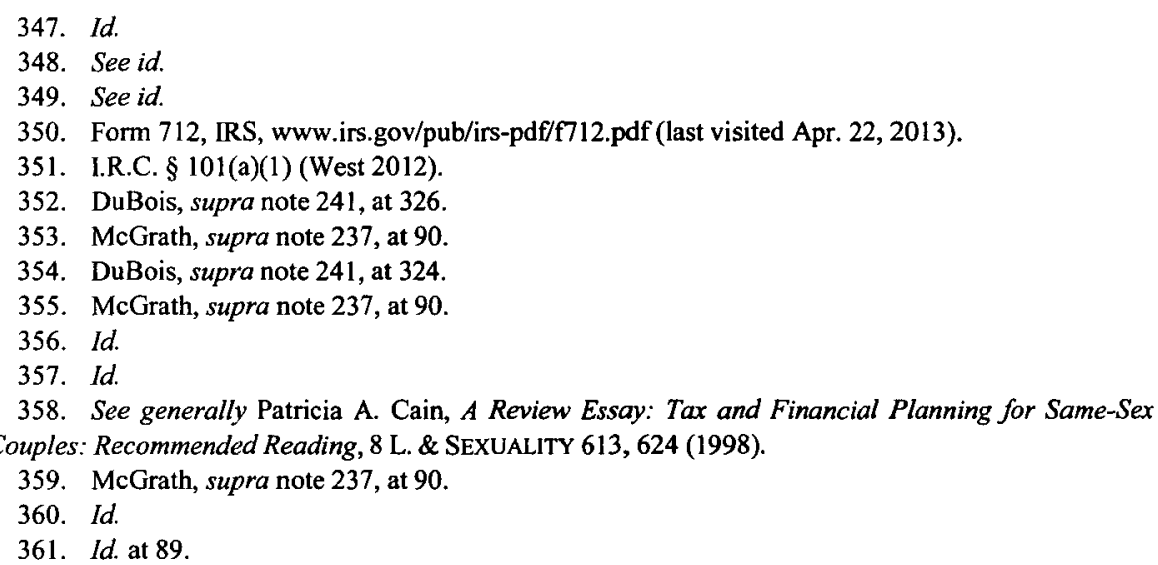


general policies of the insurance company will determine whether the couple is able to take advantage of this strategy.

As was stated above, the actual ownership of the policy will determine whether or not it is included in the estate of the deceased for estate tax purposes. ${ }^{362}$ Section 2042(2) of the Code provides that life insurance proceeds will not be included in the decedent's gross estate if the decedent relinquished all incidents of ownership to the policy and the proceeds are not payable to or for the benefit of the decedent's estate. ${ }^{363}$ Incidents of ownership generally include "the right to surrender, revoke, assign, pledge or borrow against the policy." "364 Therefore, it is advisable that the insured partner not have any control or ownership of the policy. ${ }^{365}$ One approach to this problem is to have the other partner own the policy, although problems may arise from this arrangement because of the "insurable interest" requirement that was discussed above. ${ }^{366}$ Another potential disadvantage of the beneficiary partner owning the policy is that if the partner predeceased the insured, then the value of the policy will be included in the partner's estate. $^{367}$

One way same-sex couples have solved this problem is to create an irrevocable life insurance trust to own the policy. ${ }^{368}$ This arrangement is commonly referred to as an Irrevocable Life Insurance Trust, or ILIT. ${ }^{369}$ This kind of trust will help avoid many of the problems that are associated to one partner owning the policy outright. ${ }^{370}$ In addition to the estate tax problems associated with outright ownership, issues may also arise if the relationship terminates. ${ }^{371}$ For example, the trust documents can be drafted to exclude a partner if the relationship terminates. ${ }^{372}$ Therefore, it is advisable to create an irrevocable life insurance trust and either transfer the policy in or have the trustee take out a policy on the insured so that the trust owns all incidents of ownership, rather than one of the partners. ${ }^{373}$

Again, the insurable interest requirement may prove to be a problem when setting up an irrevocable life insurance trust. ${ }^{374}$ In some states, it is unclear whether a trust can obtain a life insurance policy when the trust

362. See id. at 97.

363. I.R.C. $\S 2042$ (West 2012).

364. Goffe, supra note 11 , at 615-16.

365. See generally Cain, supra note 358, at 636 .

366. See id. at 637.

367. Goffe, supra note 11 , at 616.

368. McGrath, supra note 237 , at 95.

369. See Lewis Saret, The Necessity of Flexibility: ILITs and Estate Tax Uncertainty (May 6, 2011, 3:00 PM), www.forbes.com/sites/lewissaret/2011/05/06/the-necessity-of-flexibility-ilits-and-estate-taxuncertainty/.

370. Id.

371. Goffe, supra note 11 , at 616 .

372. Id

373. Id.

374. Id. 
beneficiary is someone without an insurable interest. ${ }^{375}$ In a state where this might be an issue, the best solution is to have the insured take out the policy and then gift it into the irrevocable life insurance trust. ${ }^{376}$

In the event that the settlor partner purchases a policy and gifts it into the trust, it should be noted that if the insured does not live more than three years, the value of the policy would be included in the insured's estate for estate tax purposes. ${ }^{377}$ This three-year requirement does not apply, however, if the trustee purchases the policy at its inception. ${ }^{378}$ This should be considered along with the laws of the jurisdiction when deciding whether to transfer a preexisting policy into the trust or have the trustee purchase the policy. ${ }^{379}$

Once the irrevocable life insurance trust is set up and the policy is owned by the trust, there are steps that the settlor must follow to make sure that this trust remains in compliance with the tax and trust laws. ${ }^{380}$ Each year, the settlor should transfer in an amount that is greater than the amount needed to pay the premiums. ${ }^{381}$ The trust documents should create "Crummey powers" that give the beneficiary the right to withdraw a certain amount after a transfer is made to the trust. ${ }^{382}$ This is done to qualify the gift as a present interest to make it eligible for the annual gift tax exclusion. ${ }^{383}$ After the right of withdrawal expires, the funds are accumulated in the trust, and the trustee can make payments on the insurance premiums. ${ }^{384}$ Once the insured partner dies, the policy matures and the proceeds will be paid to the trust to be held for the benefit of the trust beneficiary. ${ }^{385}$

Life insurance can be a very effective estate planning tool for same-sex couples, and if used properly, it can significantly increase the value of the estate that is left to the surviving partner. However, if the estate planning attorney does not know about or recognize the challenges that same-sex couples face when using this tool, it can have devastating financial consequences to the surviving partner.

\footnotetext{
375. Id

376. Id.

377. I.R.C. $\$ 2035(a)(1),(2)$ (West 2000).

378. Goffe, supra note 11 , at 617 .

379. Id.

380. Id. at 616 .

381. Id.

382. Id.

383. See generally Crummey v. Comm'r, 397 F.2d 82 (9th Cir. 1968). The court held that by creating a designated period of time during which beneficiaries of certain trusts may exercise the power to withdraw funds from the trust, the gifts subject to the withdrawal are treated as present interests that qualify for the giff-tax annual exclusion under I.R.C. Section 2503(b). Id.

384. Goffe, supra note 11 , at 616 .

385. Id. at 617 .
} 


\section{F. The Intestacy Laws}

With life insurance and jointly owned property, assets can be set up to pass on automatically at the death of one partner. ${ }^{386}$ If the couple does not take any further action in making an estate plan, however, all other assets will be subject to probate and the intestacy scheme of their particular jurisdiction, which favors consanguineous relationships. ${ }^{387}$ Currently, these intestacy laws only recognize marital, blood, or adoptive relationships when defining the heirs of the decedent who dies intestate. ${ }^{388}$ Therefore, unmarried partners will not be able to pass property to each other at the time of their death under these laws. ${ }^{389}$ The property will pass to lineal descendants or to the parents if there are no descendants. ${ }^{390}$

Because the intestacy laws promote passing property to legal family members at death, some same-sex couples have resorted to the controversial practice of adult adoption. ${ }^{391}$ The goal of this practice is to legally make the other partner a lineal descendent for the purposes of the intestacy laws, or perhaps other estate planning documents already in place to give added certainty. $^{392}$

There are many issues to consider when choosing whether or not to adopt a partner. First is the legal treatment of adult adoption in the couple's particular jurisdiction. ${ }^{393}$ Some states (and United States territories) do not permit adult adoption (including Arizona, Florida, Idaho, Nebraska, New Jersey, Ohio, and Puerto Rico), and some require that the adoptee be younger than the adopter. ${ }^{394}$ In theory, the adopter may also risk being accused of incest under the laws of that state because of the sexual relationship with the adopted partner. ${ }^{395}$ If a couple chooses to resort to adult adoption, it is important to decide who will adopt whom; ideally, the partner who is most likely to die first should adopt the other partner. ${ }^{396}$ Before choosing adoption, the partners should know that adoption cannot be

386. Annick Persinger, Still Pioneers: Special Social and Economic Hardships for Elderly Gays and Lesbians, 21 HASTINGS L. J. 137, 148 (2010).

387. Id. at 149.

388. Jennifer K. Robbennolt \& Monica Johnson, Legal Planning for Unmarried Committed Partners: Empirical Lessons for a Preventative and Therapeutic Approach, 41 ARIZ. L. REV. 417, 42324 (1999).

389. Id. at 424 .

390. Id.

391. Arthur S. Leonard, Lesbian and Gay Families and the Law: A Progress Report, 21 FORDHAM URB. L. J. 927,948 (1994).

392. Id. at 950 .

393. Goffe, supra note 11 , at 609.

394. Id.

395. Terry L. Tumipseed, Scalia's Ship of Revulsion Has Sailed: Will Lawrence Protect Adults Who Adopt Lovers to Help Ensure Their Inheritance from Incest Prosecution?, 32 HAMLINE L. REV. 95, 98 (2009).

396. Goffe, supra note 11 , at 609 . 
disclaimed or undone, and it will cause the adopted partner to lose any rights to inherit property from his or her lineal family. ${ }^{397}$

\section{G. Wills}

Intestacy is the default set of laws. ${ }^{398}$ Unless the couple plans further, property not passing automatically at death passes through intestacy laws. ${ }^{399}$ Even if the couple adapts to intestacy laws by engaging in adult adoption, using another estate planning tool such as a will or trust is advisable to ensure the estate plan carries out the intentions of the partners. ${ }^{400}$

Wills are often problematic for same-sex couples. ${ }^{401}$ The probate process makes a public document and also opens it up to challenges from the family members of the deceased partner. ${ }^{402}$ Will contests are very problematic for same-sex couples because the law favors blood-related family members, and same-sex couples face a much higher rate of these contests than the general population does. ${ }^{403}$

There are several approaches that couples who decide to execute a will can take to lessen the success of challenges. ${ }^{404}$ First, the couple must observe the strict formalities required by the laws of the jurisdiction in executing the will. ${ }^{405}$ This decreases the likelihood of successful challenges based on failure to comply with the technical requirements of executing a valid will. $^{406}$ It is also advisable that each partner has separate representation by a lawyer, as this reduces the likelihood of successful challenges based on duress and undue influence. ${ }^{407}$ Sometimes other documentation, such as a domestic partnership registration, joint lease agreement, cohabitation agreement, or any other document showing the legitimacy of the relationship can help give weight to the intent expressed in the will document. ${ }^{408}$ This is where cohabitation agreements, discussed above, are very useful, as they provide evidence of the couple's intent and the circumstances of their relationship. ${ }^{409}$

Wills are very troublesome for same-sex partners because of the lack of privacy in the probate system and the threat of post-mortem

397. Id. at 610 .

398. McGrath, supra note 237 , at 91.

399. Id.

400. Id. at 92 .

401. Goffe, supra note 11 , at 602 .

402. McGrath, supra note 237 , at 91 .

403. Id.

404. $I d$.

405. Id.

406. Id.

407. Id.

408. Goffe, supra note 11, at 609.

409. See id. at 598 . 
challenges. ${ }^{410}$ Therefore, probate avoidance is particularly important to most same-sex couples. ${ }^{41}$ In the event that a same-sex partner's family does not support the relationship or if the family members do not know the extent of the assets involved, minimizing the publicity of probate can greatly reduce the threat of a legal challenge to the couple's estate plan. ${ }^{412}$ Same-sex couples should not rely solely on a will as a way of passing property that is otherwise subject to probate because of the availability of trusts and the advantages they offer.

\section{H. Trusts}

Trusts are often the best estate planning tool for same-sex couples to pass property to their partner after death. ${ }^{413}$ Trusts keep the nature and value of the estate private in a way that wills cannot. ${ }^{414}$ Trusts, unlike wills, do not require public filing in a probate court after the death of the settlor. ${ }^{415}$ Trusts also do not require notification to heirs or other family or any sort of public inventory of the assets. ${ }^{416}$ This allows the couple to achieve the goals that they set out to achieve when making the estate plan-making the transfer of property private and less contestable.

Revocable trusts allow for control of assets during life and allow even more complex control of those assets after death. ${ }^{417}$ Revocable trusts can also provide tax advantages if used properly. ${ }^{418}$ The trust documents are flexible and can be tailored to the couple's particular needs. ${ }^{419}$ A common problem that occurs with revocable trusts is the funding of the trust with non-money assets. ${ }^{420}$ Contributing this type of asset to the trust requires retitling the asset. ${ }^{421}$ Any assets not re-titled-and thus owned by the trustend up in probate and the potential for contest greatly increases. ${ }^{422}$

Same-sex couples have options regarding what kind of trust best suits their individual situations. ${ }^{423}$ One kind of trust that might appeal to samesex couples is a joint trust. ${ }^{424} \mathrm{~A}$ joint trust is a single trust that is established

410. See McGrath, supra note 237, at 92.

411. Merrianne E. Dean, Estate Planning for Non-Traditional Families, 283 PRAC. LAW INST. 905, 909 (1999).

412. Id.

413. See McGrath, supra note 237 , at 93.

414. Id.

415. Id.

416. Id.

417. See id.

418. See Goffe, supra note 11 , at 603 .

419. See id.

420. See DuBois, supra note 241 , at 323.

421. Id.

422. Id.

423. See McGrath, supra note 237, at 93 .

424. See id. 
by both members of the couple. ${ }^{425}$ The couple places all of the assets they want to pass to the other after death into the joint trust. ${ }^{426}$ This kind of trust effectively solves problems associated with transferring property to one another after death; however, the biggest issue that the same-sex couple faces with joint trusts involves the estate tax implications of this kind of trust. ${ }^{427}$

The couple must make sure "to properly identify individually owned assets and provide separation of these assets into sub-trusts upon the death of the first partner" in the trust documents. ${ }^{428}$ This preserves the unified credit of each partner, which is the amount sheltered from the estate tax law. ${ }^{429}$ If the couple does not identify and separate the individually contributed assets, there is a risk that attribution of the entire value of the trust goes to the estate of the deceased partner, which can significantly decrease the value of the estate left to the surviving partner. ${ }^{430}$ This kind of trust may be preferable to many same-sex couples because the joint ownership and control of the trust may seem to validate or give legitimacy to the partnership on an emotional level. ${ }^{431}$

While joint ownership of a trust will be appealing to the partners, they should be aware that separate inter vivos trusts make tax planning much simpler. ${ }^{432}$ The estate planning lawyer, however, must keep in mind the social implications of the couple's property ownership. ${ }^{433}$ There is an emotional significance to the partner's joint ownership of property that the couple may not want to change. ${ }^{434}$ The couple may be reluctant to re-title important assets like the primary residence and the joint checking accounts into the name of the trust. ${ }^{435}$ As a result of this, many same-sex couples who set up inter vivos trusts may want to leave these kinds of assets out of the trusts and own them as joint tenants with the right of survival, as discussed above. ${ }^{436}$ Lawyers and tax practitioners need to be aware of these emotional issues and be prepared to work around them. ${ }^{437}$

425. See id.

426. See id.

427. See id.

428. Id.

429. See id.

430. Id. at 97.

431. See id.

432. Id. at 94 .

433. See id.

434. Id.

435. Id.

436. Id.

437. See generally, Robbennolt, supra note 388. 


\section{Estate Freezes}

As was discussed above, same-sex couples can receive substantial income tax advantages in some transactions because of the inapplicability of the related party rules found throughout the Code. ${ }^{438}$ The unmarried status of most same-sex couples may allow them opportunities to avoid gift tax liability and reduce the value of an estate for estate tax purposes.

Chapter 14 of the Code deals with transfers among family members and addresses abuses that the IRS observed in certain transactions used for the purposes of estate planning. ${ }^{439}$ These transactions are known as freeze transactions and are used to transfer property from one person to another at a reduced transfer tax cost. ${ }^{440}$ Before these rules were enacted, the typical situation involved an older taxpayer giving a gift to someone of a younger generation. ${ }^{441}$ When the taxpayer gave the gift, the value of the gift for gift tax purposes was "frozen" at the time the taxpayer gave it-the value assigned to it was the value of it in the hands of the donee at the time it was given. ${ }^{442}$ When the gift appreciated in value, the amount of the appreciation was not included in the estate of the older taxpayer. ${ }^{43}$ Various techniques have been used to reduce the value of the gift, such as the donor retaining an interest in the property or placing restrictions on it. ${ }^{444}$ Chapter 14 of the Code was enacted to prohibit or limit the tax benefit of these kinds of arrangements by not allowing reduced valuation of the gift if it is made to a family member. ${ }^{445}$ This prohibition, however, does not apply to unmarried same-sex partners because they are unrelated parties under the Code. ${ }^{446}$ The following planning techniques may be useful if the partners (or one of the partners) are wealthy enough that the estate tax will be a significant issue.

\section{Gifts of an Interest in a Business}

When an interest in a partnership or a corporation is given as a gift, section 2701 is triggered. ${ }^{447}$ This section governs the valuation of these interests when they are given for the purpose of determining whether a gift tax is applicable. ${ }^{448}$ This section becomes applicable in the event there is a

438. See supra Part II.G.

439. See, e.g., I.R.C. $\$ 2702$ (West 2012).

440. Goffe, supra note 11 , at 621 .

441. Id.

442. Id.

443. Id.

444. Id.

445. See generally I.R.C. §§ 2701-04 (West 2012).

446. See discussion, supra notes 104-05.

447. $§ 2701$.

448. Id. 
transfer of an interest in a corporation or a partnership to the transferor's family member and an applicable family member-defined therein-retains an interest in the property transferred. ${ }^{449}$ If this occurs, the gift's value will be the same as it would be in the hands of the transferor minus the retained value of the interest. ${ }^{450}$ If rights are retained immediately after the transfer and it is either a distribution right or an "extraordinary payment right," then the interest will be valued at zero. ${ }^{451}$ The retained interest is valued at zero if the transferor and the family member transferee are in control of the entity. ${ }^{452}$ The result of this valuation is that the value of the gift given to the donee will be the value of the gift in the hands of the transferor just prior to the transfer. ${ }^{453}$

Same-sex partners, on the other hand, will not qualify as "applicable family members" under this section, and the special valuation rules will not apply. ${ }^{454}$ The transfer may also be made to the child of the other partner, and this will not subject the retained interest to this special valuation rule. ${ }^{455}$ This technique is advantageous to same-sex couples when one partner is significantly wealthier than the other. ${ }^{456}$ In this situation, the value of the interest given would ideally be small when it is given to lessen the gift tax burden. ${ }^{457}$ As the entity becomes more valuable over time, the value of the interest held by the transferee will grow and an effective wealth transfer will have taken place.

\section{Grantor Retained Interest Trusts}

If one partner in a same-sex couple is significantly more wealthy than the other partner, there are many options available to the partner that allow him or her to transfer wealth and lessen the estate tax burden through the creation of a trust. ${ }^{48}$ The value of retained interests following a transfer into a trust is generally governed by section $2702 .^{459}$ This section applies when there is a transfer in trust to a family member and the transferor retains an interest in the trust. ${ }^{460}$ If the interest retained by the transferor is not a qualified interest, the value of the interest will be zero and the entire

449. $\S 2701(\mathrm{e})(1),(2)$.

450. Id.

451. See $\S 2701(\mathrm{a})$.

452. Treas. Reg. $\$ 25.2701-1$ (a)(3) (2012).

453. Id.

454. Goffe, supra note 11 , at 622.

455. Id.

456. Id.

457. Id.

458. See discussion, supra notes 358-60.

459. See Gail E. Cohen, Estate Planning for the Unique Needs of Unmarried Partners, 30 EsT. PLAN. 188, 190 (2003).

460. See I.R.C. $\S 2702(a)(1)$ (West 2012). 
value of the trust property will be subject to the gift tax if it is above the annual exclusion. ${ }^{461}$

Under section 2702, a grantor may retain qualified interests, which include an annuity interest from a Grantor Retained Annuity Trust (GRAT), a right to receive a unitrust payment from a Grantor Retained Unitrust (GRUT), and a right to remain in a personal residence that is held by a Qualified Personal Residence Trust (QPRT). ${ }^{462}$ These arrangements are standard estate planning techniques available for transfers made in trust for the benefit of an applicable family member. The valuation of the retained qualified interests is determined by section 7520 , which refers to the valuation tables that the Treasury has created. ${ }^{463}$ Same-sex couples, however, are comprised of unrelated parties and are not subject to the valuation procedures that are proscribed in section 2702. As such, samesex couples are not limited to using a GRAT, GRUT, or QPRT to achieve a reduced transfer tax liability on the transfer of assets into a trust for the benefit of the other partner. ${ }^{464}$ Unmarried same-sex couples who are legally unrelated parties are not precluded from establishing a common law Grantor Retained Interest Trust (GRIT). ${ }^{465}$ A grantor can use a GRIT to substantially reduce his or her gift tax liability, and wealthy same-sex couples can use a GRIT as a very beneficial estate planning tool.

A grantor may find that a GRIT is beneficial because his or her retained interest would not be subject to the Treasury's valuation tables proscribed in section $7520 .{ }^{466}$ Congress enacted these tables to curb the perceived abuses that the IRS observed with a GRIT by indirectly assigning a higher value to the property for gift tax purposes. ${ }^{467}$ Congress enacted section 2702 primarily to address abuses that were in the context of a settlor creating a trust for the benefit of a related family member as a means of passing wealth and reducing gift and estate tax liability. ${ }^{468}$ Therefore, if the remainder beneficiary is a member of the family of the settlor, the value of the gift is governed by section 2702. If the trust is not in the form of a GRAT, GRUT, or QPRT, the grantor's retained interest is not a qualified interest under section 2702(b). ${ }^{469}$ The reason that gifts to GRATs, GRUTs, and QRPTs are allowed a reduction in value is that the value of the interest retained by the grantor can be accurately valued at the time the gift is

461. § 2702(a)(2).

462. See Cohen, supra note 459 , at 188 .

463. See I.R.C. $\S \S 7520(a), 2702(a)(2)(B)$ (West 2012).

464. See Goffe, supra note 11 , at 623 .

465. See McGrath, supra note 237 , at 94 .

466. See Matthew Fry, One Small Step for Federal Taxation, One Giant Leap for Same-Sex Equality: Revising \$ 2702 of the Internal Revenue Code to Apply Equally to All Marriages, 81 TEMP. L. REv. 545, 560 (2008).

467. See id.

468. See id.

469. See I.R.C. § 2702(b) (West 2012). 
given. ${ }^{470}$ If the grantor's transfer to the trust was not qualified, the value of the interest would be deemed zero, and the entire amount of the gift to the trust would be subject to gift tax. ${ }^{471}$

GRITs were a very popular estate planning tool before the enactment of section 2702's special valuation rules and, in fact, they were the cause of the enactment of section 2702. ${ }^{472}$ A GRIT is an irrevocable trust that allows the grantor to retain an income interest in the trust property for a term of years. ${ }^{473}$ The property is then transferred to the beneficiary once the term of years expires, provided that the settlor is still living. ${ }^{474}$ A GRAT or GRUT is similarly arranged. ${ }^{475}$ However, the advantage of a GRIT is found in the valuation of the gift that is given. ${ }^{476}$

When a settlor transfers property into a GRIT, the value of the property for gift tax purposes is generally decreased by the value of the interest that the grantor retained in the property. ${ }^{477}$ The value of the trust property transferred, therefore, is calculated based on the amount of principal that is expected to pass to the beneficiary as calculated at the time the gift was given. ${ }^{478}$ The result of this is that the value of the gift given to a GRIT may be substantially undervalued, while the interest retained by the settlor may be substantially overvalued for the purposes of gift tax calculation. ${ }^{479}$

The settlor will pay a gift tax, if applicable, based on this reduced value and, in many cases, will be able to reduce the amount of income that he or she receives from the trust. ${ }^{480}$ The settlor's actions, in turn, increase the amount of principal that remains in the trust and the actual value of the gift given to the beneficiary. ${ }^{481}$ At the end of the trust term, the property can either be distributed outright to the beneficiary, or it can remain in the trust for future growth. ${ }^{482}$ If the settlor survives the term of years, the property transferred into the GRIT is not included in his estate for estate tax purposes. ${ }^{483}$

When section 2702 applies, the value of a grantor's gift to a trust is reduced by the interest retained by the grantor, as determined by the

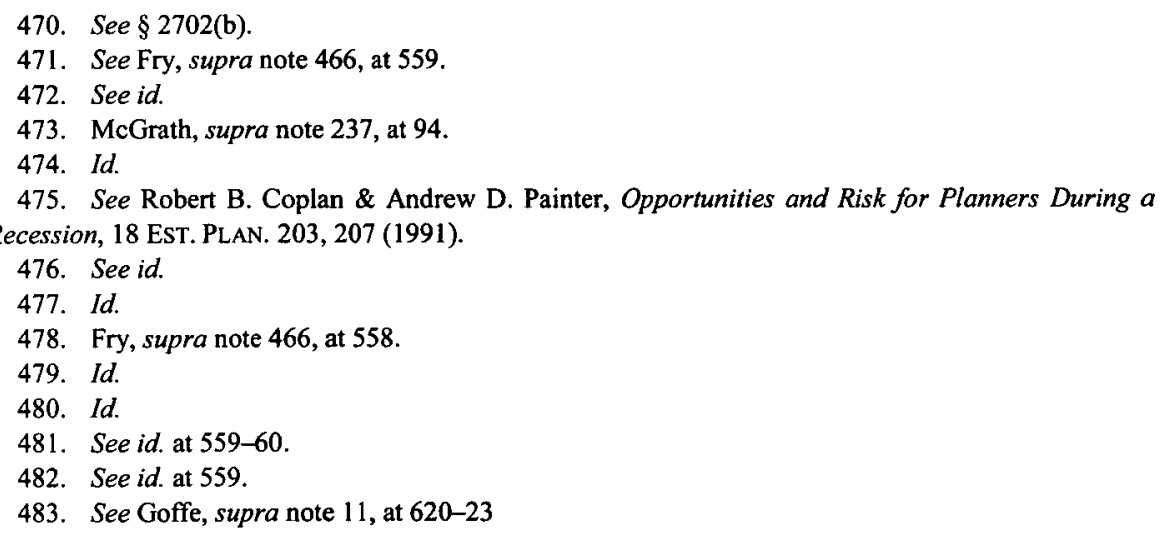


valuation tables that are cross-referenced in section $7520 .^{484}$ If a trust is created that is outside of section 2702 , the value of the assets that are transferred into the GRIT are valued with reference to the actuarial value of the trust property that is expected to pass to the beneficiary. ${ }^{485}$ The actuarial value of the property given will be substantially less than the value that would be assigned to the property under section 2072 because the Treasury's valuation tables will generally assign a lower value to the interest retained by the grantor. ${ }^{486}$

This is one of the areas of tax law in which same-sex couples have an advantage over married couples because the advantages of a traditional GRIT arrangement are lost if the remainder beneficiary is a family member. ${ }^{487}$ The gift tax savings are available because of the inapplicability of section 2702's valuation rules. ${ }^{488}$ This tool can allow a same-sex couple to transfer a large amount of assets without incurring nearly as much gift tax liability as a married couple would under a traditional GRAT or GRUT.

Same-sex couples may also take advantage of the treatment of Qualified Personal Residence Trusts as a means of transferring wealth between them. A QPRT is an irrevocable trust that can be used to transfer a personal residence to a beneficiary at a substantially discounted value at the end of the trust term. ${ }^{489}$ This type of trust is a retained interest trust and, if it is created for the benefit of a family member, the restrictions of section 2707 will apply. ${ }^{490}$

Treasury Regulations section 25.2702-5(b) gives details about the rules that govern this type of trust. ${ }^{491}$ Generally, the grantor may transfer his personal residence into an irrevocable trust for the benefit of related family member and retain the right to reside in the house. ${ }^{492}$ The trust lasts for a term of years not to exceed twenty; at the end of this time the residence and any appreciation in value passes to the beneficiary. ${ }^{493}$ When the settlor establishes the QRPT and transfers the residence into the trust, the transfer results in a taxable gift. ${ }^{494}$

The value of the gift is less than the value of the residence because of the interest that the settlor retained giving him the right to use the residence. $^{495}$ If the trust complies with the requirements of Treasury

484. See I.R.C. $\$ 2702(a)(2)(B)$ (West 2012).

485. See id.

486. See Fry, supra note 466 , at 559.

487. See $§ 2702(e)$.

488. See Fry, supra note 466 , at 561 .

489. See id.

490. See id.

491. Treas. Reg. $\S 25.2702-5$ (b) (2006).

492. Id.

493. Id.

494. Id.

495. Id. 
Regulations section $25.2702-5$, the valuation procedures in section $2702-$ discussed above-will not apply. ${ }^{496}$ This results in less gift tax liability to the transferor because the valuation procedures in section 2702 generally result in a higher value assigned to the gift than would otherwise be assigned. ${ }^{497}$ In addition, if the settlor survives the term of the trust, the residence passes to the beneficiary and the value of it will not be included in the transferor's estate for estate tax purposes. ${ }^{498}$

Unmarried same-sex couples may be able to gain another benefit from the use of personal residence trusts. If one partner establishes a personal residence trust for the benefit of the other partner, an unrelated party, then it falls outside of the scope of section 2702 and Treasury Regulations section 25.2702-5. This is beneficial for same-sex couples because this allows them the diminution of the value of the gift similar to that of a GRIT and will not subject them to the sale restrictions that the Regulation imposes. ${ }^{499}$ The Regulation requires that, for the trust to be "qualified" and have special valuation rules applicable, the trust documents must prohibit the sale of the residence from the trust to the grantor, the grantor's spouse, or an entity controlled by the grantor at any time before and after the trust term. ${ }^{500}$ Because same-sex couples are unrelated parties, these provisions do not apply to a personal residence trust created for the benefit of one partner. ${ }^{501}$

Tax planners for same-sex couples have used this arrangement to facilitate the transfer of cash or other assets from one partner to the other without incurring substantial gift tax liability. ${ }^{502}$ Because section 2702 does not apply, a grantor partner may transfer the house to the trust at a substantially reduced value, retain the right to live in it, and purchase the residence before the expiration of the trust term. ${ }^{503}$ If this is done, cash or other assets pass to the other partner in place of the residence. ${ }^{504}$ This may be an effective way to pass a substantial amount of cash from one partner to another.

\section{J. Planning for Incapacity}

Same-sex couples must also plan for a situation in which one of the partners is unable to make health care decisions for him or herself. ${ }^{505}$ Every state has a statute granting the health care decision making powers to

496. Treas. Reg. $\S 25.2702-5(a)$ (2006).

497. Goffe, supra note 11, at 572 .

498. Id. at 571 .

499. Id.

500. Treas. Reg. \& 25.2707-5(c)(9).

501. See $\$ 25.2702-5(\mathrm{a})(1)$.

502. Goffe, supra note 11 , at 571 .

503. Id. at 625 .

504. Id.

505. Robbennolt, supra note 388 , at 148. 
relatives if a person becomes incapacitated. ${ }^{506}$ If the person is married, the statutes generally give the spouse the ability to make health care decisions. ${ }^{507}$ These statutes that give the power to the spouse are based on the idea that the spouse is most likely to know what the person would want and have that person's best interests in mind when making the tough decisions. ${ }^{508}$ This same thing may be said about any devoted partner, be they same-sex partners or an unmarried couple. ${ }^{509}$ However, most stateswith the exception of New Mexico-do not provide any deference or decision-making power to an unmarried partner. ${ }^{510}$ These statutes are the default rules that same-sex couples must plan around. ${ }^{511}$

Failing to plan for this situation can have troubling consequences. If the partner does not designate the other as his or her health care decision maker, it means that the person to whom he or she is closest to will not have any control over the health care of his or her loved one. ${ }^{512}$ Furthermore, because the reality is that homosexuals are far more likely to be estranged from their family, it is possible that the person designated by statute to make health care decisions will not be emotionally close to the individual. $^{513}$

For a partner to give the other the power to make health care decisions in the event of incapacity, a partner needs to make sure the other is designated as his or her health care agent. ${ }^{514}$ The names of the documents that accomplish this are known as health care proxy, power of attorney for health care, medical power of attorney, durable health care power of attorney, or some other name; the names vary from state to state. ${ }^{515}$ This grants the other partner (the agent) the power to make the decisions for the principal in the event of incapacity. ${ }^{516}$ The most important consideration is to make sure that the agency appointment is durable to survive the incapacity of the principal. ${ }^{517}$ The document giving the agency power should not contain language that gives broad powers to the agent to make these health care decisions. ${ }^{518}$ If executed properly, a healthcare power of attorney gives the same-sex partner the ability to make the decisions for his or her incapacitated loved one. ${ }^{519}$

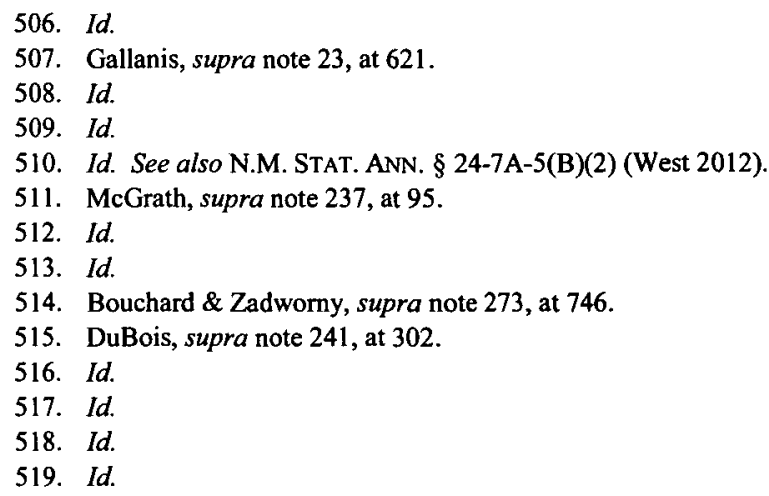


One issue facing same-sex couples in estate planning is the disclosure of privileged medical information. ${ }^{520}$ For these powers to become effective, the principal must lack capacity. ${ }^{521}$ However, if the doctor is not authorized to disclose medical information to the other partner, the doctor may be reluctant to inform the other partner when the principal is close to losing capacity. ${ }^{522}$ It is therefore important to include a provision in the health care power of attorney authorizing the agent to access medical records. ${ }^{523}$ To make this agency designation more effective, it is a good idea when dealing with same-sex couples to have them execute Health Insurance Portability and Accountability Act (HIPAA) waivers to enable the partner with capacity to have access to the medical records in the event the healthcare power of attorney is not sufficient. ${ }^{524}$

It is also advisable to include a provision that grants the agent priority of visitation rights. ${ }^{525}$ It should state that the agent shall be the first person to visit with the principal and the attending physician in the event of incapacity and that the agent has the right to limit who else can visit the principal. ${ }^{526}$ This provision is very important to same-sex couples because it shows the primary physician that the agent not only has priority over treatment decisions but also has priority in the principal's family structure. ${ }^{527}$ This will lessen the possibility of conflict between the physician and the agent. ${ }^{528}$

When the health care power of attorney is executed, it is a good idea to also execute an advanced directive listing the types of treatments that are authorized and specify when treatment is not to be done. ${ }^{529}$ When this type of document is made and the person becomes incapacitated, the question then becomes whether or not a kind of treatment complies with the wishes of the incapacitated. ${ }^{530}$ This is why it is important to have a health care power of attorney along with the advance directive; if this is not done, it is left to the attending physician or a relative to determine whether a course of action complies with the wishes of the incapacitated. ${ }^{531}$

The statutory requirements of advance directives vary from state to state. $^{532}$ In fact, many states require that the language that creates the advance directive be included in the healthcare power of attorney

520. Bouchard \& Zadworny, supra note 273 , at 747 .

521. Id. at 746 .

522. Id.

523. DuBois, supra note 241 , at 302.

524. Bouchard \& Zadwomy, supra note 273 , at 713.

525. DuBois, supra note 241 , at 302.

526. Id.

527. Id.

528. Id.

529. Id.

530. Id.

531. Robbennolt, supra note 388 , at 422.

532. Id. at 423 . 
documents. ${ }^{533}$ For same-sex couples, the advance directive can give the partner guidance when making hard healthcare decisions for the other and can also work to reduce conflict that might arise between the agent and the family members of the principal. ${ }^{534}$ Generally, it is important for the principal to provide as much documentation of his or her wishes as possible to reduce the risk of a possible legal challenge to the other partner's decisions. ${ }^{535}$

\section{K. Funeral Planning}

As same-sex couples seek to establish an estate plan, the partners need to consider how they want their funerals conducted and what disposition should be made of their bodies. Partners who do not plan for this may find that the funeral of the deceased partner is planned contrary to the deceased's wishes. ${ }^{536}$ In most jurisdictions, the disposition of the body, including funeral arrangements, is to be decided by the next of kin unless there are specific instructions otherwise. ${ }^{537}$ Same-sex couples should therefore provide specific instructions regarding preferred funeral arrangements and whether the body should be buried or cremated, and they should provide that the surviving partner should have authority to make such decisions. ${ }^{538}$ If a person has a preferred funeral home where they wish for the funeral to take place, he or she may want to consider providing that funeral home with the written instructions before death occurs. ${ }^{539}$ The partners should take care to see that these documents, along with all estate planning documents, remain accessible to the other partner or family members so that the extensive planning for these end of life issues are not ignored. ${ }^{540}$

\section{CONCLUSION}

The legal rights and legal status of same-sex couples is uncertain in many areas. The number of states that recognize same-sex marriage is

533. Id.

534. DuBois, supra note 241 , at 302.

535. Bouchard \& Zadworny, supra note 273 , at 749.

536. Id. See also MetLife MATURE MKT. Inst. \& Lesbian \& Gay AGNG ISSUEs Network of THE AM. SOC'Y ON AGING AND ZOGBY INT'L, OUT AND AGING: THE METLIFE STUDY OF LESBIAN AND GAY BABY BOOMERS 4 (2006).

537. DENIS Clifford, FREDERICK HERTZ \& EMILy DOSKOW, A LEGAL GUIDE fOR LeSBIAN AND GAY COUPLES 133 (14th ed. 2007).

538. Daryl J. Finizio, Funeral Planning Agent Designation: An Unused But Useful Tool for Same Sex Couples, R.I. B.J., Mar. 2007, at 31 (Rhode Island, for example, has enacted a law in order to address this issue. "To address these concerns, the Funeral Planning Agent Designation law was enacted. This law provides a legal means of designating an agent who would have authority to conduct the decedent's funeral and oversee the disposition of the decedent's remains.").

539. Bouchard \& Zadworny, supra note 273 , at 749 .

540. Id. 
expected to rise in the next few years. ${ }^{541}$ Most states, however, are not required to give full faith and credit to same-sex marriage decrees from other states. ${ }^{542}$ In addition, the decision in United States $v$. Windsor has yet to be reviewed by the Supreme Court. ${ }^{543}$ Most same-sex couples, however, will be unaffected regardless of the outcome of this case. ${ }^{544}$ For these couples, the income tax planning strategies discussed in this article will be useful as they structure their finances as a single economic unit. Tax practitioners who are hired by these couples must be aware of these tax planning strategies to effectively represent these clients.

As a significant portion of the population reaches the age in which estate planning becomes a major concern, there will inevitably be a rise in the number of same-sex couples who seek competent legal professionals to meet their planning needs. ${ }^{55}$ Data taken from the 2000 census showed that for every 100 non-elderly adults, there were 20.1 elderly adults, elderly being defined as people over the age of $65 .{ }^{546}$ Based on that data, it is expected that the proportion of elderly adults will increase to 35.6 for every 100 by $2020 .{ }^{547}$ Traditional estate planning is based on planning for married partners but as was discussed above, these traditional estate planning methods may be adapted to meet the needs of unmarried same-sex couples. ${ }^{548}$ Adapting these methods can give the couple the ability to enjoy some of the rights and privileges that are generally denied because of their unmarried status and can reduce estate and gift tax liability that can lessen the value of the deceased partner's estate. ${ }^{549}$

To successfully adapt these methods to meet the needs of these clients, tax practitioners must always keep in mind the emotional complexities that are involved in same-sex relationships, as these emotional complexities may limit the tools that they are willing to use. ${ }^{550}$ The emotional aspect of the relationship and the relative wealth of the parties will often affect how they prefer to deal with financial matters, such as the decision whether to pool assets or keep them separated. ${ }^{551}$ This will be contrary to the general assumption when dealing with married couples that the assets are going to be commingled rather than separated. ${ }^{552}$ Practitioners must also be aware of

541. Chris Weiss, Same-Sex Marriage: 7 States Most Likely to Legalize Gay Marriage in 2013, POLICY MIC (Jan. 2013), http://www.policymic.com/articles/22346/same-sex-marriage-7-states-mostlikely-to-legalize-gay-marriage-in-2013.

542. See 28 U.S.C. $\S 1738$ (2009).

543. See U.S. v. Windsor, 133 S. Ct. $786(2012)$.

544. Weiss, supra note 541.

545. Id.

546. Persinger, supra note 386 , at 138.

547. Id.

548. Id.

549. Id.

550. Robbennolt, supra note 388, at 429.

551. See Chase, supra note 3, at 360.

552. Robbennolt, supra note 388 , at 429. 
the legal challenges that same-sex couples will face when creating their estate plan because the law considers them to be legal strangers. ${ }^{553}$ By recognizing the legal and emotional reality of these relationships and preparing for the interaction that these relationships will have with state and federal laws, practitioners will be able to effectively modify these traditional estate and tax planning approaches to meet the needs of nontraditional same-sex couple clients. 